\title{
Institutional Design and Implicit Incentives in Bolivia's Decentralization Model
}

\section{Diseño institucional e incentivos implícitos en la descentralización boliviana}

\author{
Gover Barja Daza* \\ Sergio Villarroel Böhrt** \\ David Zavaleta Castellón ***
}

\begin{abstract}
The second generation fiscal federalism (SGFF) approach is used as a reference to analyze the political and fiscal institutional design of Bolivia's decentralization model and its evolution. Subnational public finance data up to 2008 is used to verify that decentralization of expenditure was higher than that of revenue, establishing a context of vertical fiscal imbalance that increased due to growing fiscal transfers during the positive external shock (boom) period. Consequently, the subnational fiscal surplus was not a result of internal efficiency but of excess revenues from such transfers. Panel models were estimated to identify and assess the implicit incentives embedded in fiscal institutions of the decentralization model.
\end{abstract}

Findings at the municipal level are: i) misalignment of local spending with local interests due to dominance of transfers over own revenue (dominance of central government development policies); ii) incentive to spend transfers faster than own revenue (flypaper

Professor at Maestrías para el Desarrollo (MPD) of the Universidad Católica Boliviana San Pablo (UCB). Contact: gbarja@mpd.ucb.edu.bo

** Professor at Maestrías para el Desarrollo (MPD) of the Universidad Católica Boliviana San Pablo (UCB). Contact: villabohrt@gmail.com

***Professor at Maestrías para el Desarrollo (MPD) of the Universidad Católica Boliviana San Pablo (UCB). Contact: dzavaleta@mpd.ucb.edu.bo 
effect); iii) greater marginal contribution of own revenue to positive fiscal balances compared to transfers, thus introducing the seed for a soft budget constraint but hidden by the fiscal surplus; iv) disincentive to generate own revenue (tax and non-tax) due to the size and growth of transfers (disincentive to the culture of contributing to own revenue).

Findings at the prefectural'level are: i) misalignment with regional interests given the dominance of transfers over own revenue due to absolute lack of tax powers (until 2009); ii) high tendency to a soft budget constraint and, eventually, also fiscal bail-out, hidden by the fiscal surplus; iii) in only two departments collection of national-level taxes were higher, compared to transfers received in the same departments; iv) disincentive to pay the VAT (national-level tax) due to higher royalty transfers received, an effect not extended to other national-level taxes; v) high dependence from hydrocarbon-based transfers, and fiscal risk when this natural resource declines (both in volume and prices) due to volatility of international oil prices. Also, as a result of the decentralization model a positive and significant impact was found on education-coverage indicators, an important development objective of the national government.

Keywords: Second generation fiscal federalism; Panel models; Bolivia.

\section{Resumen}

Se utiliza el enfoque de segunda generación de descentralización fiscal como referencia para establecer las características del diseño de la institucionalidad política y fiscal de la descentralización boliviana y su evolución. Se utilizan datos hasta 2008 de las finanzas públicas subnacionales para verificar en lo fiscal que la descentralización del gasto fue mayor que la del ingreso, estableciendo un contexto de desbalance fiscal vertical que fue creciente por el aumento de las transferencias fiscales durante el periodo de auge. Tal contexto establece que el superávit fiscal subnacional experimentado no fue por eficiencia interna sino por ingresos excesivos provenientes de dichas transferencias. Se estimaron modelos de panel para

1 From the territorial point of view, Bolivia is organized in 9 departments (intermediate level) and 337 municipalities. Before 2006, each department had a Prefecture as its executive branch (in practice a deconcentrated arm of the national government) and only municipalities were considered autonomous or truly decentralized since the Popular Participation Law was enacted in 1994. In 2006, Prefectural authorities were elected for the first time. However, Prefectures became autonomous Gobernaciones only after the new Constitution was enacted in 2009, meaning that they gained self-government capacity through own laws emerging out of their legislative bodies (called departmental assemblies or Asambleas Departamentales). The Constitution introduced the new concept of indigenous territories, leaving room for misinterpretations (a fourth level). However, these indigenous territories (once they achieved autonomous status) are supposed to exercise their autonomy through the municipal level. 
identificar y evaluar los incentivos implícitos contenidos en la institucionalidad fiscal de la descentralización.

En el ámbito municipal se encuentra: (i) desalineamiento del gasto local con los intereses locales por dominancia de los ingresos no propios (transferencias) sobre los propios (dominancia de las políticas de desarrollo del Gobierno central); (ii) incentivo a gastar ingresos no propios más rápidamente que los propios (efecto flypaper); (iii) mayor contribución marginal de ingresos propios a saldos fiscales positivos que de ingresos no propios, generándose así la semilla de presupuesto flexible (soft budget problem), pero oculto por el superávit fiscal; (iv) desincentivo a la generación de ingresos propios (tributarios y no tributarios) por efecto de la magnitud y crecimiento de los no propios (desincentivo a la cultura de aporte propio).

En el ámbito prefectural se encontró: (i) desalineamiento con los intereses regionales por predominancia de los ingresos no propios (transferencias), al no existir acceso a impuestos propios; (ii) tendencia potencial al problema de presupuesto flexible y salvataje fiscal (bail out) también oculto por el superávit fiscal; (iii) solo dos departamentos generaron impuestos de nivel nacional mayores a las transferencias que recibieron; (iv) desincentivo a pagar el impuesto nacional IVA a causa de mayores transferencias por regalías, efecto no extendido a otros impuestos nacionales; (v) dependencia y riesgo fiscal frente a la disminución de precios y volumen de producción de hidrocarburos debido a la volatilidad de precios del petróleo. En términos de resultados se encontró impacto favorable y significativo de la descentralización sobre indicadores de educación, que fue objetivo de desarrollo del Gobierno central.

Palabras clave: Federalismo fiscal segunda generación; Modelos de panel; Bolivia.

Classification/Clasificación JEL: H71, H72, H73, H75, H77, C33.

\section{Introduction}

Bolivia’s decentralization model can be analyzed from different perspectives. In this case the proposal is to focus on the performance of fiscal decentralization ${ }^{2}$ under the conceptual approach of Second Generation Fiscal Federalism (SGFF). Under the First Generation

2 Depending on a country's political structure, fiscal arrangements between different tiers of government can be called fiscal federalism (federal systems) or fiscal decentralization (unitary states). In this paper both terms are used interchangeably. 
Fiscal Federalism (FGFF) approach it is a function of the public sector, in its multiple levels of government, to identify and correct market failures such that social welfare is maximized. Emphasis was on designing fiscal transfers to correct for vertical and horizontal imbalances (Musgrave, 1959; Oates, 1972). Criticism of this approach is that it builds theory on the assumption that intervention and action of public officials occurs under full and symmetric information and for the common good (benevolent government).

The SGFF approach builds theory under the opposite assumption, that public officials are agents with political interests, and make decisions with incomplete and asymmetric information seeking to maximize their interests in the political context in which they happen to operate (Weingast, 1995 and 2009; Qian and Weingast, 1997). The literature on SGFF combines political economy with the economics of information, thus allowing analysis of decentralization focused on the implicit incentives contained in its political and fiscal institutions and the behavior induced by these incentives in a context of asymmetric information (Oates, 2005).

Weingast (1995 and 2009) presents a set of conditions (D1-D5) for market preserving political institutions of decentralization and reference (in this case, a reference to "efficiency") for evaluation of other institutional arrangements. These are: (D1) a hierarchy of governments exists with each level having a delineated scope of authority, in other words, a clear vertical division of power exists; (D2) subnational governments have authority over local regulation of the economy and over public goods and service provision, meaning that they have the authority to adapt policies to their circumstances; (D3) the national government provides for and polices a common market that allows factor and product mobility, therefore promoting an effective competition among jurisdictions; (D4) all governments, especially subnational ones, face hard budget constraints to avoid spending beyond their means and bailouts; and (D5) the allocation of political authority is institutionalized, so that the decentralization scheme does not fall under the discretionary control of the national government, instead, a set of institutions must exist that prevent the national government from altering the rules.

In theory the fulfillment of the five conditions ensure that decentralization would create an environment of competition among local jurisdictions (efficiency), this being the reason for calling them market-preserving political institutions. Failure to meet one or more of these conditions would help to explain and understand the behavior of other possible institutional arrangements. The objective of promoting inter jurisdictional competition should be understood from the perspective of (1) the sources of competition (D2, D3 and D4); (2) 
competition itself as incentive to implement policies in line with local interests (the deeper economic concern); and (3) the effects of such competition in correcting local misalignment coming from government and private agents as well as citizens of a jurisdiction.

The following clarifications, additions and precautions should be added to this theoretical approach. First, in practice a country could implement a decentralization scheme different from that proposed by Weingast. Decentralization could be pro-market, pro-government or a mix in-between. The issue is that, regardless of the type of decentralization implemented, it still requires comparison to something in order to understand and evaluate it. Following the tradition of normative economics, that something would have to be efficiency, in this case the D1-D5 conditions. Second, condition (D5) is intended to function as a lock so that decentralization is not modified or reversed unilaterally by central government ${ }^{3}$. The concern arises from the double dilemma of decentralization of DeFiguereido and Weingast (1997): what prevents the national government from destroying decentralization by rolling over subnationals units ${ }^{4}$ ? and what prevents local jurisdictions from undermining decentralization by free-riding and other forms of failure to cooperate ${ }^{5}$ ? To survive, a federal system must resolve both dilemmas. For Qian and Weingast (1997) the solution is in the design of political institutions of decentralization that achieve alignment of incentives of political agents with the interests and welfare of local residents. So the fundamental political problem is the same economic problem of misalignment and its solution is again promoting interjurisdictional competition. Third, and as a precaution, for Prud'homme (1995) the idea of interjurisdictional competition is desirable while promoting efficiency, as opposed to it being destructive. Alternatively and not frequently mentioned in the literature, is the visualization of a desirable degree of competition combined with sub-national governments cooperating with each other spontaneously or as a result of incentives and regulations that come from the national government.

While conditions D1-D5 describe the political institutions of reference, fiscal institutions refer to the design of detailed tax and transfer policies, the implicit incentives they lead to and

3 In the Anglo-Saxon tradition the ultimate goal of decentralization (as opposed to centralization) is to limit the concentration of political power in a central government (Weingast, 1995). In contrast to most recent Latin American tradition the ultimate goal would have been facing the social debt (Finot, 2005).

4 Abuse of power is known in the literature as "the problem of predatory government" (North, 1990). Its effect is to discourage economic agents.

5 The attitude of saving or continue to fund inefficient public services, programs or public enterprises is known in the literature as "the problem of soft budget" (Kornai, 1986; Kornai, Maskin and Roland, 2003). Its effect is to encourage wasteful spending and not avoid mistakes. 
results they generate. In this area, design of transfers is particularly critical for achieving the objectives of equalization, along with encouraging local economic growth.

Possibly one of the most interesting contemporary experiences from the perspective of design of political and fiscal institutions of decentralization is the case of China (Jin, Qian and Weingast, 2005). In contrast, there is the experience of much of Latin America (Wiesner, 2003 and Finot, 2005). The Bolivian literature on this subject has been largely dominated by the first-generation approach. To remedy this weakness becomes the first challenge of the current paper. We will evaluate Bolivia's fiscal decentralization experience using the lens of the second-generation approach, hoping to produce new ways of understanding decentralization and contribute to future innovations in this area.

Regarding organization of the document, the second section develops a theoretical framework firmly rooted in the SGFF approach as well as contrast between both approaches. This contrast allows distinguishing between different possible institutional designs and their relationship with the concepts of market-preserving, promotion of competition and tax incentives. The contrast also guides identification of performance evaluation criteria of decentralization institutions. This framework is then applied to the conceptual analysis of political and fiscal institutions of decentralization implemented in Bolivia. The third and fourth sections use the framework's evaluation criteria to identify and compute incentive variables and outcome variables for the subnational levels (municipal and intermediate or prefectural $^{6}$ ). Alongside control variables are also identified. The next step is estimation of panel models using most disaggregated variables of subnational public finances. Thus, these two sections explain quantitatively why decentralization has performed the way it did. Finally conclusions are presented in section five.

\section{Theoretical framework}

The mix of political economy and institutional economics applied to the issue of decentralization, under the second generation approach, is complex due to its multi dimensionality. Therefore it is necessary to analyze decentralization through a theoretical framework that reduces the problem to some of its key elements, allowing derivation of implications to be tested. The framework proposed here conceives different decentralized

6 As mentioned in footnote 1, Prefectures became Gobernaciones after the new Constitution was enacted in 2009 However, given that our data sample goes up to 2008 , we continue using the term Prefectures. 
economic-development alternatives depending on how several key decentralization policy options are combined. Assuming that there are only two levels of government (central and local) and following the conditions D1-D5 in a partial way, policy options could include:

i) Administrative decentralization

Vision and role of local government:

- Option P1: Local governments produce only public goods. This option corresponds to a vision of development where government is involved only in correcting market failures and development is guided under private sector leadership.

- Option P2: Local governments produce public goods and only private goods with high social impact. This option corresponds to a vision of development where government not only corrects market failures, but coexists with a private sector while taking leadership of economic development.

Economic regulation:

- Option R1: Local governments are free to adjust economic regulations to local circumstances and to local flow-needs of labor and capital between jurisdictions.

- Option R2: Local governments have partial freedom (or none) to adjust economic regulations, established by central government, to local circumstances and to flow-needs of capital and labor between jurisdictions.

ii) Fiscal decentralization (from the revenue side)

Local government financing:

- Option F1: Exclusively through own taxes to local property and local businesses. This option corresponds to a local (fiscal) administration with hard budget constraint.

- Option F2: Exclusively through transfers from the national (or departmental) government. This option corresponds to a local (fiscal) administration with soft budget constraint.

iii) Political decentralization

Local leader:

- Option E1: The public authority (local-jurisdiction leader) is elected locally through a direct democratic process. 
- Option E2: The public authority (local-jurisdiction leader) is appointed by the central government.

iv) Political economy of decentralization

Local leader incentives:

- Option I1: The motivation of the public authority (local-jurisdiction leader) is based on his own political interests.

- Option I2: The public authority (local-jurisdiction leader) has no motivation other than his own social responsibility of maximizing welfare (benevolent agent).

Policy options could be combined in many ways, leading to alternative models of decentralized development-structures. In all cases the existence of free mobility of goods and factors is assumed (common market), so this is not a policy option. The resulting arrangements could be those presented in Table 1 .

\section{Table 1}

Alternative models of decentralized development-structures under common market

\begin{tabular}{|l|l|c|c|c|c|c|}
\hline \multicolumn{2}{|c|}{$\begin{array}{c}\text { Institutional design of } \\
\text { decentralization }\end{array}$} & $\begin{array}{c}\text { Pro-market } \\
\text { Model }\end{array}$ & $\begin{array}{c}\text { Pro-state } \\
\text { Model }\end{array}$ & $\begin{array}{c}\text { Mixed } \\
\text { Model 1 }\end{array}$ & $\begin{array}{c}\text { Mixed } \\
\text { Model 2 }\end{array}$ & $\begin{array}{c}\text { Mixed } \\
\text { Model 3 }\end{array}$ \\
\hline \multirow{2}{*}{ Administrative } & Vision & P1 & P2 & P1 & P2 & P2 \\
\cline { 2 - 7 } & Regulation & R1 & R2 & R1 & R2 & R1 \\
\hline Fiscal & Finance & F1 & F2 & F2 & F1 & F2 \\
\hline Political & Election & E1 & E2 & E1 & E2 & E2 \\
\hline Political economy & Incentive & I1 & I2 & I2 & I1 & I2 \\
\hline
\end{tabular}

Source: Authors' own elaboration

In the pro-market model the local government produces only public goods and promotes private sector leadership of development; is funded solely with own local taxes; has freedom to adjust regulations to local needs; the local leader is elected in the jurisdiction; and, finally, is motivated by his own interests. This model corresponds to Weingast's proposal, in the sense that local development will only take place if decentralization is pro-market (assuming that the promotion of competition between jurisdictions will ensure a proper alignment of interests). By definition, the proposed pro-market model is pro-efficiency, which means that it does not necessarily take into account equity considerations. 
In the pro-state model the local government produces public goods plus high socialimpact private goods; is funded solely with transfers; has partial or no freedom to adjust economic regulations established by the central government; the local leader is appointed by the central government; and is motivated by his own social responsibility. The problem with this model, compared with the pro-market one, is that it promotes soft budgets along with subnational governments spending beyond their own-revenue sources. Also, the local leader must promote the expansion of a state-led economy without being able to change national regulations, but forced to follow central government guidelines.

Mixed model 1 differs from the pro-market model in that local government funding comes exclusively from transfers and the local leader is motivated by his own social responsibility. The problems with this model, compared with the pro-market one, are that it promotes subnational government overspending and bail-outs because of soft budget constraint. Also, the local leader genuinely promotes expansion of the local private sector by adjusting economic regulations to local needs, even at the expense of local fiscal deficits.

Mixed model 2 differs from the pro-state model in that local government funding comes exclusively from own local taxes and the local leader is motivated by his own political interests. Problems with this model compared (again) with the pro-market one, are that the local leader must promote expansion of a state economy in their local area, but unable to adjust economic regulations to local needs and with no financial support from central government. That is, the local leader must convince his voters to pay taxes for the construction of a centralized stateled economy. If the local leader achieves this goal would be rewarded with opportunities for advancement within the party that appointed him to that jurisdiction.

Mixed model 3 differs from the pro-state model in that local jurisdictions are free to adjust economic regulations to local needs and local leader's motivations are their own social responsibility. Problem with this model, compared with the pro-market one, is that the highly responsible local leader is assigned to a subnational jurisdiction (by the central government) with the mission to expand the state-led economy in the area, having the possibility to overspend (supported by soft budgets) and freely adjust economic regulations to local needs.

In all mixed models there is no reason to dismiss the coexistence of taxes and transfers in local government's finance, with corresponding implications regarding a certain degree of soft budget. Similarly, regarding local leader incentives, it may be divided between a mix of national political interests and local social responsibility. The above are just a few models within a 
range of possible combinations. The exercise allow us to display alternative decentralized development models, simplifying reality to only five variables, noting that change of only one of them can produce a very different reality. This helps us understand decentralization in an integral way, beyond their fiscal specificities. The exercise also shows the advantage of having a fixed reference (pro-market scheme) that can help understand and evaluate other alternatives. Of course, that doesn't mean that the pro-market model must necessarily be the correct one for any context.

Once the institutional framework of decentralization is defined (ex ante or uncovered ex post), and having identified the combination of variables $\mathrm{P}, \mathrm{R}, \mathrm{F}, \mathrm{E}$ and I, it is natural to start asking how such institutions perform in practice. In this area several critical elements of assessment can be extracted from the SGFF approach. First is the idea of alignment, i.e., whether the use of decentralized financial resources are in fact aligned with local people's interests or rather with the interests and development vision of the central government (the misalignment problem). Second, the soft budget problem versus the hard budget alternative. Soft budget encourages subnational governments to spend more than what they generate, knowing (or betting) that the central government will not allow them going bankrupt. Third, the incentive to use own-source revenues (generated locally) versus dependence on fiscal transfers. A problem related to the above but with own characteristics is the flypaper effect, which comes from the first-generation literature (Hines and Thaler, 1995; Gamkhar and Shah, 2007; Aragon, 2008). It refers to a local government having the incentive to spend transfers more quickly than locally generated revenue. Fourth the absence of barriers to competition and/or interjurisdictional cooperation aimed at promoting a pro-market environment. Fifth the need to know if the institutional design of decentralization and implicit incentives had a real impact on development.

The institutional design of Bolivias decentralization model (within the range of possibilities explained above), compared with the reference institutions (efficient or promarket), is presented in Table 2, summarizing the application of the theoretical framework and terminology to the evolution of political and fiscal institutions for the Bolivian case. 
Table 2

Evolution of Bolivia's decentralization institutions under common market ${ }^{7}$

\begin{tabular}{|c|c|c|c|c|c|}
\hline \multirow{2}{*}{\multicolumn{2}{|c|}{$\begin{array}{l}\text { Institutional design of } \\
\text { decentralization }\end{array}$}} & \multirow{3}{*}{$\begin{array}{c}\begin{array}{c}\text { Municipal } \\
\text { level } \\
(1994-2008)\end{array} \\
\text { P1 }\end{array}$} & \multicolumn{2}{|c|}{ Departmental level } & \multirow{3}{*}{$\begin{array}{c}\text { Municipal and Departmental } \\
\text { level under the new } \\
\text { constitution of } 2009\end{array}$} \\
\hline & & & $(1995-2005)$ & (2006-2008) & \\
\hline \multirow{2}{*}{ Administrative } & Vision & & $\mathrm{Pl}$ & $\mathrm{Pl}$ & \\
\hline & Regulation & R2 & R2 & R2 & R2 \\
\hline Fiscal & Finance & $\mathrm{F} 2^{*}$ & F2 & F2 & F2 \\
\hline Political & Election & El & E2 & El & El \\
\hline Political economy & Incentive & 11 & 11 & 11 & 11 \\
\hline
\end{tabular}

Source: Authors' own elaboration.

$\left({ }^{*}\right)$ Only a small proportion of large municipalities that manage to fund much of their expenses with own revenue from own tax collection could be considered as F1.

Identifying the driving forces behind Bolivia’s decentralization process, helps explaining some of the results subsequently achieved. As a starting point, it is useful to turn to the analysis of whether decentralization was promoted by bottom-up or top-down forces. In the first case two possibilities can be identified: i) forces that have its origins at the departmental or intermediate level; and ii) forces that emerged from the municipal or local level. ${ }^{8}$ Although it is true that pressures from both levels existed, the departmental one gathered momentum just years before the decentralization policy was adopted. Before the 1994 reform, a decentralization law project with departmental focus was unanimously approved by the Senate, however, the project was never considered by the House of Representatives due to pressures of the main opposition party (Movimiento Nacionalista Revolucionario, MNR). In the municipal case, only provincial and departmental capital cities had elections before the reform 9 . Also only 61 municipalities received tax-sharing transfers (Graham, 1997), making the rest financially unviable. According to Rojas Ortuste (1997) in the municipal elections of that period, peasant interest and, in general, interest of provincial inhabitants was low and poll absenteeism high. As a consequence, municipal presence (in practice) in the country was very weak, and its ability to put pressure or force a reform in favor of that level was virtually nonexistent. Regarding top-down forces, several explanations can be found, like an adequate institutional context in favor of reforms in the political arena of the national level (mentioned in Gray-Molina et al.,

7 A more detailed discussion of this table can be found in the original article in spanish by Barja, Villarroel and Zavaleta (2012).

8 Articles that provide greater insight on this topic are those of Roca (2005 and 2007) for the departmental case and Rodriguez (1995) for the local case.

9 A total of 124, according to Molina Saucedo (1997). 
1999), an attempt to follow recommendations from multilateral agencies ${ }^{10}$, and an interest to use decentralization to compensate the unpopular capitalization (privatization) of SOEs policy, adopted by the national level. Another explanation (purely electoral) might be the one presented by O'Neill (2003 and 2005), who points out that presidential electoral procedures at the national level generated the incentives for a decentralization reform ${ }^{11}$. There is also the need to solve the problem of a "state with holes" (in the interpretation of O'Donnell, 1993) referred to the discontinuity of state presence given its spatial distribution over the territory ${ }^{12}$.

In short, the explanations presented so far show that in the first half of the nineties a bottom-up demand for decentralization arose from the departmental level, which coincided with top-down decentralization intentions that had political and technical support. The reason why the latter top-down decentralization tendency ended up favoring the municipal level, can be found in the political vision of the ruling party that took office in 1993 (MNR) and the personal position of its leader Gonzalo Sanchez de Lozada, then president of the republic. As mentioned by Finot (2003) doctrinally the MNR was always against a political decentralization towards the departmental level, arguing that it could jeopardize national unity due to unequal distribution of natural resources among regions. Sanchez de Lozada shared this concern and rejected decentralization proposals aimed at the departmental level to avoid, in his view, possible confrontations and even secession (see Roca, 2007). So the only viable option for Sanchez de Lozada was to rely on the municipal level as the main territorial protagonist of the decentralization process, and made this happen through the Popular Participation Law. Afterwards, the Administrative Decentralization Law was enacted trying to calm regional demands. However, in practice, that law only deepened the deconcentration scheme toward departments, using prefectures (former executive branch of that level with appointed authorities) solely as an operating arm of the national government.

The above description is useful if seen in the context of what was proposed by Bird (1993) and Bird and Vaillancourt (1998). The contribution of these authors highlights the

10 Note that the year of reform the World Bank suggested in a document that proper implementation of reforms required complementary policies like decentralization, civil service, and restructuring of the judiciary power (see Reid and Malik, 1994). Furthermore, note that Bolivia has been ranked by some authors as a country that followed "by-the-book" the policy reforms recommended by multilateral agencies (see Stiglitz, 2002).

11 In the author's words: "Because the procedures for choosing the president leave each party uncertain of gaining or attaining the presidency despite potentially strong electoral showings, every party has some incentive to seek a decentralized system in which power is more disaggregated and therefore easier to grasp at many levels of government. To determine which parties will favor decentralization, one must look to their support at subnational levels and at the stability of their support over time. Both of these criteria shed a spotlight on the MNR, the system's most stable party across elections and the only party with consistent, widespread support throughout the country, particularly in rural areas" (O'Neill, 2005: 157).

12 This view has been widely developed in a UNDP report (PNUD, 2007). 
criteria needed to properly evaluate a fiscal decentralization model. According to Bird (1993), regardless of the stimulus for opting for a top-down decentralization, the main criterion for evaluating fiscal decentralization should be how well it serves the presumed national policy objectives, because when processes are initiated from above, the rationale behind the assignment of responsibilities to subnational units is precisely to achieve more efficiently the goals of the national level (Bird and Vaillancourt, 1998). One of the most important goals of central governments is to increase the level of "national" welfare (as opposed to a bottom-up approach where increasing "local" welfare is the guiding principle). Furthermore, Bird suggests that when public policy preferences of the national level are clearly dominant, the appropriate analytical framework in this setting is clearly a principal-agent model in which the principal (the national government) may alter jurisdictional boundaries, local government revenue and expenditure responsibilities, and intergovernmental fiscal arrangements in its attempt to overcome the familiar agency problems of information asymmetry and differing objectives between principal and agent (Bird, 1993).

Returning to explanation of the variables contained in Table 2, it is only after the 1994 reform (Popular Participation Law) that Bolivia adopted a true hierarchy between levels of government (D1 in terms of Weingast, 2009), with areas of authority delineated for the municipal and national levels. Even though a real vertical division of power was not formally implemented (this happened later in 2009 with the approval of the new Constitution), because lawmaking power remained exclusively at the national level; municipalities acquired important degrees of self-rule (administrative and financially). The following are the main features of the institutional context and evolution of the decentralization reform.

The vision that prevailed from 1994 to 2008 (at the national, departmental and municipal level) was that private sector should lead economic development and government would limit its interventions to economic regulation and the correction of market failures, particularly the provision of public goods. The central government's concern with regard to subnational-level actions was rather dominated by social needs (a view consistent with the top-down approach where national preferences prevail). This deepened in the 2000s when public investment geared towards poverty reduction and subsequently to the achievement of the MDGs ${ }^{13}$. Subnational productive development was rather left to the private sector under a common

13 Four studies have addressed so far the impact of Bolivia's decentralization on poverty reduction, three with positive findings (Gray-Molina, 2004; Grootaert and Narayan, 2004; Ajwad and Wodon, 2007) and one with skeptic results (Inchauste, 2009). There is also an old article that explored in a preliminary way (only three years after the reform) the impact of the decentralization model on inequality (Escalante, 1997) suggesting that a positive effect on equity was emerging. 
market policy and free mobility of products and factors across jurisdictional boundaries, which ultimately favored the concentration of economic activity in the three main capital cities of the geographic central axis (La Paz, Cochabamba and Santa Cruz). This does not mean that subnational levels lacked functions or responsibilities related to the promotion of productive activities, because in fact they had, but the most important interventions had a strong bias towards investment in social areas (education and health) and basic infrastructure (roads, power, sanitation and other) ${ }^{14}$. Investment supporting productive activities was on average less than $10 \%$ in the case of municipalities and less than $20 \%$ in the case of prefectures, as can be seen in Figures 1 and 2.

The change of vision, at all levels, came with the adoption of the new National Constitution of 2009, as it gives the state a more active and leading role in promoting economic development, reverting the orthodox market-led orientation initiated in 1985. In practice the new vision (strongly influenced by the ruling party's ideology) came to reality through a number of nationalizations of strategic extractive companies, implementation of manufacturing state-owned industries in various sectors, restriction on exports to ensure domestic supply, and even some price controls at times of scarcity.

14 In an interesting and frequently quoted study (based on the municipal level) Faguet (2004) found that: i) public investment patterns changed with the implementation of the decentralization reform in education, water and sanitation, water management, agriculture and urban development; and ii) these changes were strongly and positively related to real local need's indicators in these sectors, especially in poor rural municipalities. Faguet's results suggest that preferences were properly identified and addressed, successfully re-directing investment to match local needs. According to Oates (1972) this will promote greater efficiency in public spending and, therefore, higher levels of development. However, the latter direct causal effect has not yet been tested empirically. It is also important to note that Faguet's approach is based on quantitative targets, which is consistent with a top-down vision that seeks to achieve greater coverage-targets set by the national government (the focus on qualitative goals is more demanding in terms of local participation). In the current paper we follow a different approach. Our point of departure is that subnational governments cannot match investment to local preferences if their main source of funding are transfers and not own revenue, which has been the case of almost all municipalities (except big urban ones) since the beginning of the reform. 
Figure 1: Municipal Investment

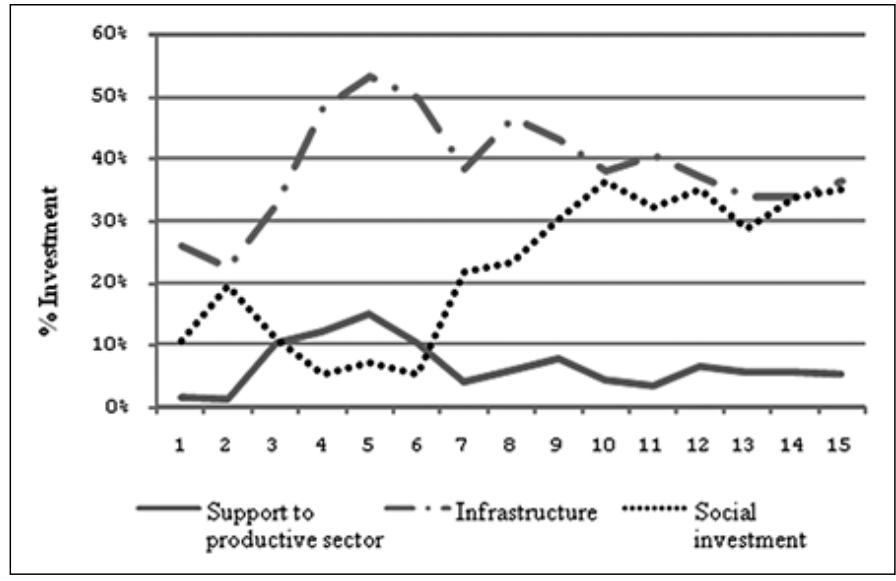

Source: Authors' own computations

Figure 2: Prefectural Investment

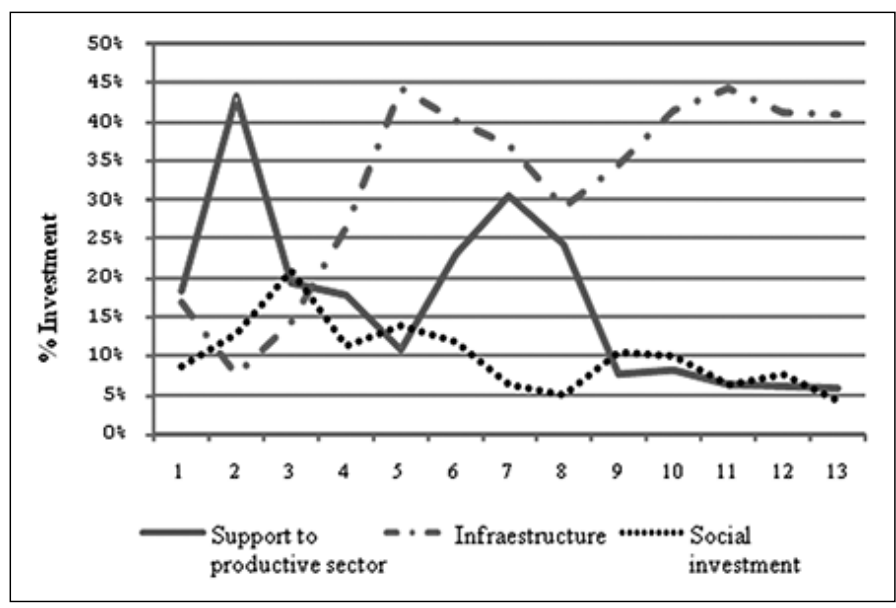

Source: Authors' own computations

Policies related to the regulation of economic activity throughout the period analyzed (even after the adoption of the new Constitution) where almost exclusively determined by the national level. Note that regulation is understood here in a generic sense, as the promotion of free competition where possible (helping markets work properly), the regulation of 
monopolies and oligopolies, and other mechanisms oriented to solve coordination failures between agents, reduce information asymmetries and prevent the proliferation of negative externalities. From this perspective both, municipalities and the intermediate level, have little or no regulation responsibilities.

As far as financing is concerned, transfers dominate over own revenue at the municipal level throughout the period of analysis. Transfers have been growing gradually and in the boom period (2006-2008) they experienced substantial additional growth. However, it should be borne in mind that the situation varies between urban and rural municipalities, since the former are in a better position to collect own taxes ${ }^{15}$ given their administrative capacity and degree of development that exists in densely populated centers. On the contrary, most rural municipalities lack these favorable conditions, thus becoming more dependent on the transfer system ${ }^{16}$. These conditions imply a double-dimension funding as large municipalities could cover their expenses largely through own tax revenues, thus facing a hard budget constraint, while small municipalities are funded almost entirely by transfers, which puts them in a position of soft budget constraint ${ }^{17}$. At the departmental level dependence on transfers was very high from the very beginning (over 90\%) because until 2008 that level had no own taxes at all (thus establishing an administration with strong features of soft budget, with all the complications that this implies), and transfers received were also growing over time, especially during the boom period. In this respect, it is important not to lose sight of the fact that the national government collects in the departments (geographically speaking) all taxes that belong to its domain, and then redistribute them according to precise formulas (see Appendices 1 and 2) associated to public policy objectives (top-down approach). Once the vision and its financing was established, the public administration was divided into a role of tax collection (responsibility of the national level) and another role of expenditure (assigned to subnational governments), both demanding important intergovernmental cooperation and coordination $^{18}$.

15 Municipal taxes were until 2008: i) the real estate property tax ; ii) the vehicle property tax; iii) the tax that levies the transfer of these real estate and vehicles; and iv) a small tax on the consumption of a fermented beverage based on corn, called chicha. The 2009 Constitution added a motor-vehicle environmental pollution tax.

16 Note also that the transfer system (see Appendix 1) is strongly based on equity considerations (with per-capita distribution as the main criteria) as is characteristic of FGFF models, thereby hurting small rural municipalities where population is reduced.

17 Some studies like Wiesner (2003) have criticized Bolivia's decentralization indicating that subnational governments were given insufficient capacities (incentives) or authority over public policy, allowing soft budgets constraint based on debt relief. The study notes that Bolivia would have increased transfers without increasing local responsibilities, something that is shared by the World Bank (2006).

18 Note that all significant transfers (see Appendix 2) have its origins in the surplus generated by the exploitation and export of hydrocarbon resources, thus introducing an additional risk of transfer volatility linked to changes in 
Even though the new Constitution and more precisely the TaxDefinition and Classification Law (Law 154 of 14/07/2011) introduced changes to tax domains at the departmental level; these are not relevant enough to reverse their current dependence on transfers. Article 7 of the Law establishes that Departments may create taxes subject to the following taxable events: i) hereditary succession and donations of real and personal property subject to public registry, ${ }^{19}$ ii) ownership of motor vehicles for air and water navigation ${ }^{20}$ and iii) negative impacts to the environment ${ }^{21}$ (except those caused by motor vehicles, hydrocarbon activities, mining and electricity). The potential collection from these taxes will be small, but still represents progress. The challenge now is to build good subnational tax administrations capable to fully exploit the taxable events granted and complement them with an effort on non-tax revenue sources.

As for the election of authorities or political leaders at the municipal level, mayors were directly elected from the start of the 1994 reform, while at the departmental level authorities benefited from this procedure since 2006. However, there are two aspects that can affect direct election: i) at the municipal level the experiences of the so called "constructive-censorship veto power", set in the old Constitution, allowed the removal of elected mayors before the end of their legal term ${ }^{22}$; and ii) in the framework of implementation of the new Constitution the introduction of the controversial Article 144 in the Law of Autonomy and Decentralization, which provides for the temporary suspension of elected authorities after a formal (legal) accusation, has led in recent years to weaken the institution of election by direct vote, and to date there are several sub-national authorities who have been dismissed under this mechanism. Only recently (2013), the Constitutional Court declared that this article is unconstitutional.

international prices. Moreover, an important point noted by the World Bank (2006) is that the criteria used to allocate resources among departments does not serve to correct horizontal imbalances. An aspect that plays a key role is the geographical origins of hydrocarbons, where producing departments receive more transfers while nonproducing ones receive equal amounts regardless of population size or wealth. This implies that transfers are highly inequitable between departments when they are evaluated in per capita terms. In fact, the new hydrocarbons law (and therefore the Direct Tax on Hydrocarbons - IDH) has worsened the horizontal disparities. All these stems from an underlying element of Bolivia's regional fiscal pact (according to the same World Bank document), which is that each time a "producing" department obtains a higher share; the "non-producing" departments have to be compensated with additional funds from the National Treasury (TGN). This imposes additional fiscal pressures on the treasury to access new resources unrelated to hydrocarbons.

19 In Bolivia the immediate predecessor is the National Free Property Transmission Tax, which will remain in effect until the departmental governments create their own taxes. Records show that collection of this tax is currently very small, equivalent to approximately $0.06 \%$ of total revenues.

20 In a small country like Bolivia, with few aircrafts and structurally landlocked, the revenue-generating capacity of taxes like these is very low.

21 Depending on design a tax of this nature could become interesting; however, evasion possibilities complicate its management.

22 For further references see Luján (2004). 
Finally it is considered that the political economy incentive of subnational authorities throughout the period was more aligned with their own political interests, rather than with social-welfare maximization motives. The mechanisms for removal of elected officials are indicators of the prevalence of own political party interests of local authorities, not necessarily benevolent but rather guided by personal political objectives.

In short, Table 2 provides the institutional framework of Bolivia's decentralization model until 2008, characterized as a mixed case (P1, R2, F2, E1, I1) and predominantly pro-market in practice (a greater weight can be assigned to the P1 criterion, in addition to the common market), despite the significant government presence in centralizing policies on economic regulation, equity and decentralization-financing as a whole. The weakness of this model, compared to the pro-market (efficient) alternative, is that subnational governments are funded primarily through transfers, which promotes dependency and incentive to spend more than own revenue (despite the reduced budget-execution in some cases ), along with soft budgets constraints and misalignment with local interests. The strength of the model is that local leadership allows private sector freedom to develop in an environment of interjurisdictional competition among companies, with free flow of products, services, people and companies among localities, being this the most pro-market policy that prevailed over time, encouraging migration and greater concentration of economic activity in the nation's (geographical) central axis. While on the one hand policy promoted access to equal opportunity in education and health at the municipal level, on the economic front it promoted a policy of free factor mobility and strengthening of the three major centers of economic activity (La Paz, Cochabamba and Santa Cruz) that are better connected to globalization.

A question remains whether the recent constitutional reforms established a new combination of policy options that will correct identified problems and improve the chances of achieving new social and economic objectives, given the new balance of political forces and current level of economic development. The last column of Table 2 describe the new combination of policy options (P2, R2, F2, E1, I1) which basically changes only the vision, from development with a pro-market bias towards a new pro-state orientation. However, given that the most pro-market policy has not changed, free mobility of private factors towards their most efficient use (territorially speaking), the applicability of the new vision of development can, in reality, be very difficult. 


\section{Incentives in municipal fiscal decentralization}

What matters methodologically under the second generation approach is to measure the connection, direction and impact of incentives contained in the political and fiscal institutions of decentralization. This means studying the relationship between incentive variables and outcome variables, as well as the characteristics and strengths of their connection. This implies, first, to identify incentive and outcome variables and, second, estimate models contrasting theory with the Bolivian experience. The models of interest in the municipal decentralization are the following:

i) A model to establish the characteristics of alignment;

ii) A model of hard or soft budget constraint;

iii) A model of own revenue collection;

iv) A model of the impact of institutional design and their implicit incentives.

Following Jin, Qian and Weingast (2005: 1732) the following fixed effects model can be used to estimate coefficients that establish correlation between the variables of interest:

$$
Y_{i t}=\alpha_{i}+\gamma_{t}+\beta X_{i t}+Z_{i t} \delta+\mu_{i t}
$$

Where $Y_{i t}$ is an outcome variable in municipality i in year $\mathrm{t}, X_{i t}$ is the incentive variable in municipality i in year t, $Z_{i t}$ is a set of control variables, the $\alpha_{i}$ are fixed effects by municipalities, $\gamma$ are annual dummies, $\beta$ is the correlation coefficient to be estimated, $\delta$ are the coefficients of the set of control variables and $\mu_{i t}$ are disturbances. As indicated above, the objective in all cases (except maybe iv) is to estimate the strength of connection between $Y$ and $X$ variables, that is, to accurately establish correlation, not causation.

Estimation of different panel models is done with available and detailed municipal fiscal data obtained from the ForoDAC Fiscal Laboratory ${ }^{23}$. The following are the variable definitions used, all in real terms $\left(1990\right.$ Bolivians $\left.^{24}\right)$ and per capita basis:

1. Total revenue of a municipality is the sum of own and not-own revenue;

2. Own revenue includes tax and non-tax revenue;

23 A government effort to generate a subnational fiscal data base. The project was discontinued in 2010

24 The currency in Bolivia is the Bolivian (Bs) and in 1990 the average exchange rate was 3,17 Bs per U.S. dollar. 
3. Tax revenue includes real estate property taxes, motor vehicles property taxes, and taxes on property transfers;

4. Non-tax revenue includes technical fees, rights, patents and concessions, contributions for improvements, fines, penal interest, foreign exchange gains, other unspecified income, operating income, sales of goods and services, interest and other property rents and own capital income;

5. Not-own revenue includes current transfers from the national government due to revenue-sharing from a basket of national taxes (coparticipacion tributaria) and the Direct Hydrocarbon Tax (IDH tax-sharing), plus capital transfers from the national government due to HIPC II, plus donations;

6. Donations are not-own revenue and includes the accumulation of all kinds of private and foreign transfers, either current or capital;

7. Total expenditure of a municipality is the sum of operating expenses, investment expenses and the remainder;

8. Operating expenditure includes goods and services and personal services. It corresponds to an average to $89 \%$ of current expenditure;

9. Expenditures on personal services includes salaries, allowances, social security and employer contributions for housing;

10. Investment expenditure relates to projects or real investment, corresponding to an average to $96 \%$ of capital expenditure;

11. The remainder includes all types of current and capital transfers to the public, private and foreign sectors, plus interest and fees and other expenses (this variable was not included in regressions).

The following control variables were also used in estimating the different models:

i. Decentralization measures representing municipal and departmental institutions of fiscal decentralization. This measurement followed Martínez-Vázquez and Timofeev (2009).

ii. Poverty measures. The initial asset poverty is approximated by the unsatisfied basic needs index computed by UDAPE for 2001 for each municipality; as an alternative, initial income poverty is also used, which is approximated by the Foster, Greer and Thorbecke index (FGT) computed by UDAPE for 2001 for each municipality. Other alternative 
used is a measure of initial human capital, approximated by the human development index computed by UNDP and UDAPE for 2001 for each municipality.

iii. Per capita departmental gross domestic product (GDP) as a measure of the economic environment in which each municipality performs. Departmental GDP fluctuations resulting from diversity of economic factors impact all municipalities alike.

iv. An indicator of differences in initial local development visions, culture and customs, approximated by the multidimensional indicator of indigenous proportion, computed by UDAPE for 2001 for each municipality. It is multidimensional because it results from a combination of the many languages spoken plus self-declaration of belonging.

v. Net initial migration as the immigration minus emigration experienced by each municipality, published in population terms in the 2001 census by the National Institute of Statistics (INE) for each municipality. When negative, the municipality is net ejector of population.

vi. The proportion of population of each municipality engaged in agricultural activities, published in the 2001 census (initial). The opposite ratio establishes occupation in any other non-agricultural activity (mining, industry, trade and services). A more agricultural municipality tends to be more traditional and lagged in terms of incorporating innovations.

vii. Geopolitical dummies as follows: High Lands include all municipalities in the departments of La Paz, Oruro and Potosi; Valleys includes all municipalities in the departments of Cochabamba, Chuquisaca and Tarija; Low lands include all municipalities in the departments of Santa Cruz, Beni and Pando.

Except for the municipal decentralization variable and departmental GDP per capita, the other control variables are constant over time but vary between municipalities. To take advantage of this wealth of information in practice model (1) is estimated using a random effects model.

In order to provide an overview on the behavior of local governments, here are some stylized facts. Following the methodology of Martínez-Vázquez and Timofeev (2009) for the measurement of subnational revenue and expenditure decentralization (see Appendix C for details), we see that revenue decentralization at the municipal level was larger than at the prefectural level (the latter was practically nonexistent), but at the same time expenditure decentralization at the prefectural level was larger compared to the municipal level. Aspects that reflect an important design feature of the political and fiscal institutions of Bolivia's decentralization model. 
As for the structure of municipal revenues, it evolved in a particular way. Figure 3 a shows the rapid growth of public policy transfers (PP Transf) over the decade, possibly discouraging own revenues given that their participation stalled, which also reveals the degree of dependence of the municipal level to this source of revenue. A breakdown of transfers (Figure 3b) shows that revenue-sharing was the most important source of revenue, adding to it the IDH source but only in recent years, while the debt relief source (HIPC II) was always relatively small except in 2002 and 2003.

Figure 3: a) Municipalities revenue

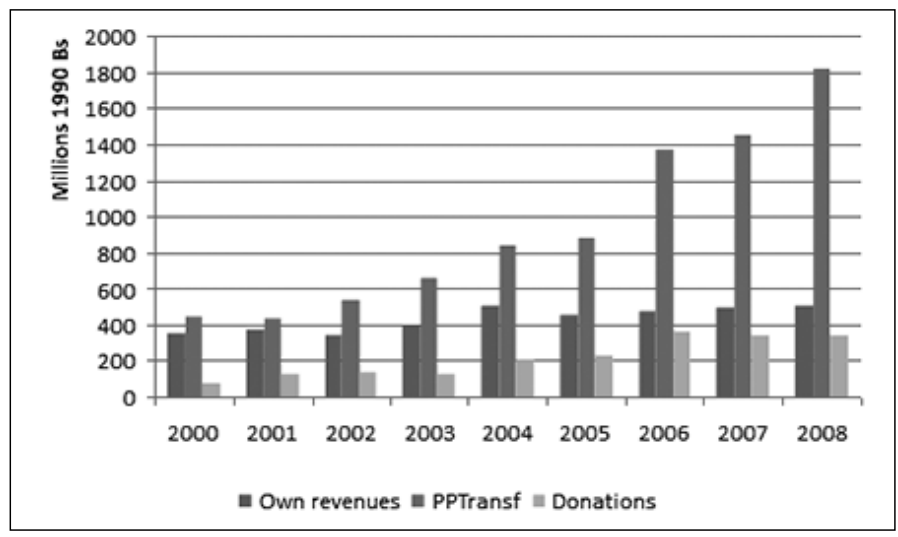

Source: Authors' own elaboration

b) Structure of transfers

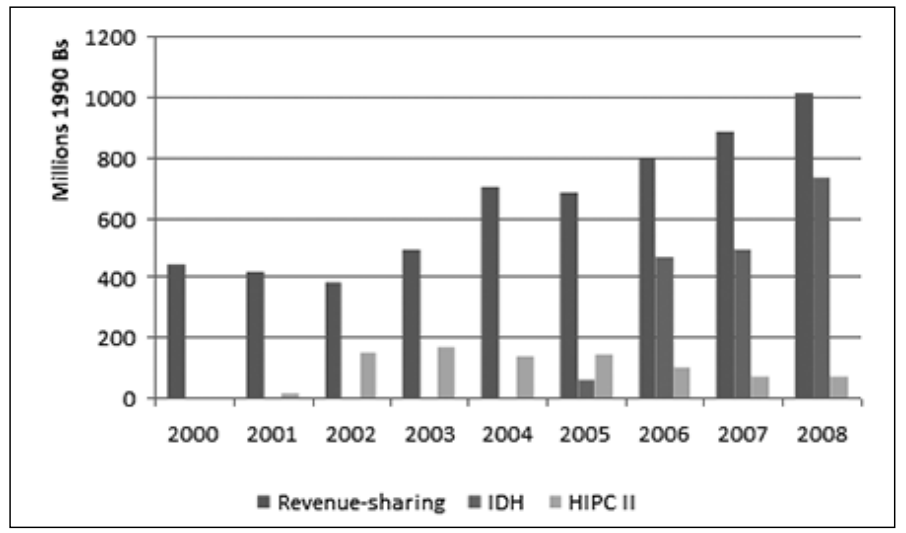

Source: Authors' own elaboration 
Also during the 2000-2008 period, a significant growth of per capita municipal income can be observed since 2006, consistent with the beginning of the boom period experienced by the Bolivian economy. The average per capita municipal income rose from Bs. 80.70 to Bs. 385.68 during the studied period, with the strongest variation between years 2005 and 2006 as shown in Table 3 .

\section{Table 3}

Per capita income by municipality 2000-2008 (1990 Bs.)

\begin{tabular}{|l|r|r|r|r|r|r|r|r|r|}
\hline & \multicolumn{1}{c|}{$\mathbf{2 0 0 0}$} & \multicolumn{1}{c|}{$\mathbf{2 0 0 1}$} & $\mathbf{2 0 0 2}$ & $\mathbf{2 0 0 3}$ & \multicolumn{1}{c|}{$\mathbf{2 0 0 4}$} & $\mathbf{2 0 0 5}$ & $\mathbf{2 0 0 6}$ & \multicolumn{1}{c|}{$\mathbf{2 0 0 7}$} & $\mathbf{2 0 0 8}$ \\
\hline Average & $\begin{array}{r}80,70 \\
(81,25)\end{array}$ & $\begin{array}{r}71,16 \\
(66,48)\end{array}$ & $\begin{array}{r}86,25 \\
(90,49)\end{array}$ & $\begin{array}{r}120,71 \\
(80,41)\end{array}$ & $\begin{array}{r}144,59 \\
(73,58)\end{array}$ & $\begin{array}{r}171,17 \\
(93,87)\end{array}$ & $\begin{array}{r}283,10 \\
(266,58)\end{array}$ & $\begin{array}{r}314,73 \\
(248,17)\end{array}$ & $\begin{array}{r}385,68 \\
(339,17)\end{array}$ \\
\hline Median & 76,59 & 76,82 & 103,61 & 113,60 & 120,52 & 144,66 & 215,29 & 242,34 & 283,16 \\
\hline Variation\% & & 0,30 & 34,87 & 9,64 & 6,09 & 20,02 & 48,82 & 12,56 & 16,84 \\
\hline
\end{tabular}

Source: Authors' own elaboration. Numbers in parentheses are standard deviations.

Figure 4a shows the distribution of per capita income of the 327 municipalities in real terms (1990 Bs.) for the years 2000-2008. Between the years 2000-2005 per capita municipal income was below Bs. 1,000 for all municipalities. Years 2006-2008 show that per capita municipal income increased significantly for many municipalities, even surpassing the Bs. 2,000 barrier in a couple of cases. It can be said that 2000-2005 corresponds to the pre boom period and 2006-2008 to the boom period. An inherent characteristic of municipalities is their wide dispersion of sizes also in terms of per capita income. Figure $4 \mathrm{~b}$ shows an ordering of per capita income from lowest to highest for the 327 municipalities for the period 2000-200825. The graph shows basically two groups of municipalities if Bs. 500 is used as an arbitrary cutting criterion. Following Table 4, approximately $96 \%$ of municipalities belong to the group of per capita income less than or equal to Bs. 500, with an average income of Bs. 152.27 per capita. In contrast there is a small group of about $4 \%$ of municipalities with income higher than Bs. 500 per capita, with an average of 944.16 Bs. per capita.

25 Multiplying the 327 municipalities by 9 years produces a total of 2,943 possible observations, to which no data cases are subtracted, producing 2,878 cases actually observed. 
Figure 4: a) Per capita revenue

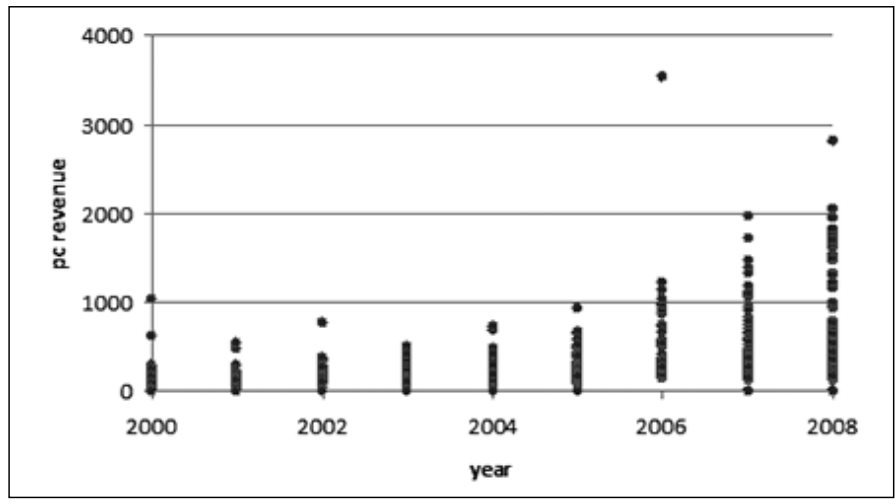

Source: Authors' own elaboration. pc = per capita

b) Ordered per capita revenues

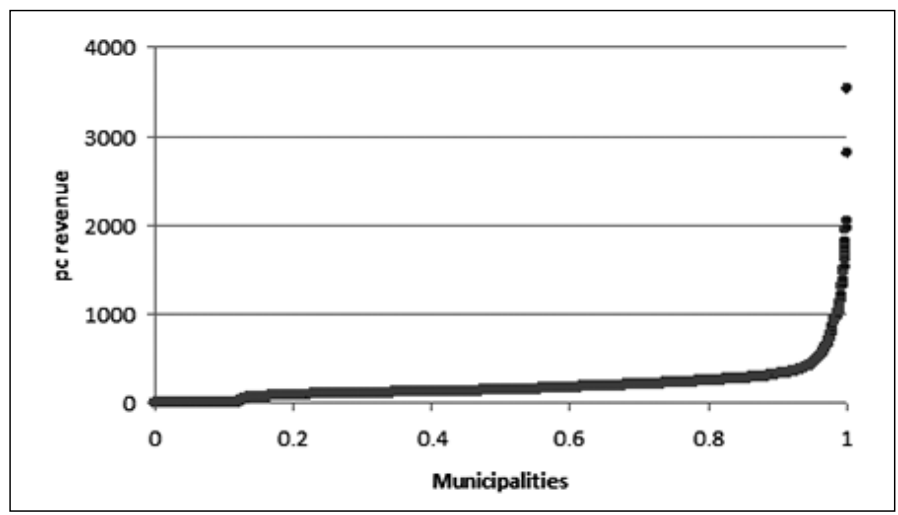

Source: Authors' own elaboration. pc = per capita

Table 4

Per capita income of municipalities in 2000-2008 (1990 Bs.)

\begin{tabular}{|l|c|c|c|}
\hline \multicolumn{1}{|c|}{ Per capita income } & Income $\leq \mathbf{5 0 0}$ & Income $\mathbf{5 0 0}$ & Total \\
\hline Number of municipalities & 2.755 & 123 & 2.878 \\
\hline \multirow{2}{*}{ Average } & 152,27 & 944,16 & 186,12 \\
& $(98,62)$ & $(470,14)$ & $(210,59)$ \\
\hline Median & 136,50 & 788,35 & 140,85 \\
\hline
\end{tabular}

Source: Authors' own elaboration 


\section{Municipal alignment}

Central to the theory is the issue of alignment between revenue and expenditure. The more correlated these two variables, the better the alignment between the interests of public officials (who decide on expenditures) with the interests of citizens that generate (own) revenue. Following model (1), per capita municipal expenditure is used as the $\mathrm{Y}_{\text {it }}$ variable and different individual measures of per capita revenue are used as the $X_{\mathrm{it}}$ variable. The period 2000-2005 is considered pre boom and 2006-2008 is the boom period, so models are estimated for both of these, but also for the whole period 2000-2008. As shown in Table 5, several breakdowns of revenues are considered, emphasizing separation between own municipal revenues resulting from local effort and not-own municipal revenues resulting from national-level and foreign effort. The municipal population published by the 2001 Census (initial population) was used every year in the transformation of monetary variables to per capita. The Table presents only the correlation coefficients of interest (Appendix 4 presents details of estimated model for the period 2000-2008) $)^{26}$.

\section{Table 5}

Municipal correlation coefficients of the expenditure-revenue relationship, pc

\begin{tabular}{|c|c|c|c|}
\hline Dependent: Expenditure pc & $\mathbf{2 0 0 0 - 2 0 0 5}$ & $\mathbf{2 0 0 6 - 2 0 0 8}$ & $\mathbf{2 0 0 0 - 2 0 0 8}$ \\
\hline Own revenue pc & $0,740^{* *}$ & $0,250^{* * *}$ & $0,348^{* * *}$ \\
\hline Tax pc & $1,792^{* * *}$ & $0,221^{* * *}$ & $0,217^{* * *}$ \\
\hline Nontax pc & $0,675^{* *}$ & 0,338 & $0,537^{* * *}$ \\
\hline Not-own revenue pc & $0,936^{* * *}$ & $0,753^{* * *}$ & $0,819^{* * *}$ \\
\hline Revenue sharing pc & $1,519^{* * *}$ & 0,904 & $1,384^{* * *}$ \\
\hline IDH pc & $0,753^{* *}$ & $1,035^{* * *}$ & $1,106^{* * *}$ \\
\hline HIPC II pc & $1,708^{* * *}$ & 1,181 & $1,748^{* * *}$ \\
\hline Donations pc & $1,056^{* * *}$ & $0,605^{* * *}$ & $0,896^{* * *}$ \\
\hline
\end{tabular}

Source: Authors' own elaboration. See Appendix 4 for details of results for the period 2000-08.

*** Significant at 1\%; ** significant at $5 \%$; pc = per capita.

The first row shows that in period 2000-2005 a Bolivian of own per capita revenue was associated with a per capita expenditure of 74 cents. This ratio decreased significantly

26 In short panels, the emphasis is to exploit the richness of variability between individuals rather than between periods (appropriate given the heterogeneity of behavior of municipalities explained by variables specific to each municipality and mostly omitted). This determines models with greater attention to structural relationships. Also, when using variables in levels (probably not stationary) rather than differences (stationary), more attention is given to long-term or structural effects rather than short term. Annual dummy variables are introduced to capture the effect of time and reduce potential spurious relationships. Also dummy variables were used for department capital cities to control for the potential effect of outliers and spatial effects. 
to 25 cents in period 2006-2008. When revenues are not-own (forth row) then per capita expenditure was of 93.6 and 75.3 cents per Bolivian of per capita revenue in 2000-2005 and 2006-2008 respectively. In both cases, correlation of expenditure with own revenue is less than with not-own revenue, independent of the period. The result suggests that expenditures were primarily aligned to not-own revenue, confirming the existence of misalignment with local interests (as predicted by the SGFF approach). While in the first period alignment of expenditures with not-own revenues was already greater than with own revenues, the difference was not excessive, which no longer occurs in the second period, where alignment of expenditure to not-own sources of revenue dominate.

Moreover, in both cases coefficients are smaller in the second period, possibly reflecting lower expenditure capabilities, but with relevant differences. Expenditure of own revenue decreases $66.2 \%$ between periods, while expenditure of not-own revenue decreases only $19.5 \%$. This goes along with the fact that not-own revenues tend to be spend faster than own, $26.4 \%$ faster in the first period and $201.2 \%$ faster in the second period, confirming the existence of a flypaper effect ${ }^{27}$.

Within own revenue sources, both tax and non-tax explain the strength of alignment of own revenue to expenditure during period 2000-2005, the first more than double than the second. However, the strength of this alignment drops dramatically in the second period, in $87.6 \%$ for tax revenues and $100 \%$ for non-tax revenues (as it is not statistically significant). Within not-own revenues sources, there is a change in the structure of influence between periods. In the first period all sources of not-own revenues are statistically significant and in the following order of strength of influence: HIPC II, revenue-sharing, other donations and finally IDH (the latter entered into force in 2005). In contrast, in the second period only IDH and donations are statistically significant, the first is not only more important than the second, it is dominant.

In short, while in the first period there was some misalignment between expenditure autonomy aligned to own revenue, compared to dependency and alignment to not-own revenue, this conflict has worsened in the second period and predominantly due to the effect of IDH. In this case another effect can be added to misalignment and flypaper, that of

27 An observed empirical regularity in the literature. Explanation of why this is the so-called flypaper effect is debated since the 60s under the first-generation approach. For some authors it is an anomaly because it contradicts the theory (Hines and Thaler, 1995), for others it is just an econometric problem, but for most there is a theoretical explanation (see a review by Gamkhar and Shah, 2007 and the work of Aragon, 2008 and Dahlby, 2010). 
the "natural resource curse" given that IDH has its source in the hydrocarbons sector ${ }^{28}$. The third column of Table 5 summarizes considering the whole period 2000-2008, consistently confirming coefficients for not-own revenue sources greater than own revenue sources, reflecting the main outcome of the institutional design of municipal decentralization.

Appendix 4 also shows summary of behavior of control variables in estimation of the different models, which inform on context characteristics of municipal decentralization. The initial poverty variable measured by unsatisfied basic needs for housing and services (NBI2001) presents a positive sign, i.e. this type of poverty that has to do with public goods promote municipal expenditure. In contrast, the monetary poverty variable (capability poverty for income generation) measured by the proportion of households living below the poverty line (Poverty2001) presents a negative sign, i.e. it discourages or hinders municipal expenditure. Moreover, the variable that reflects local culture measured by the proportion of indigenous population (Indigenous2001) and the variable representing main economic activity measured by the share of employment devoted to agriculture discourage or hinder greater expenditures. Instead the net migration variable (immigration-emigration2001) presents a positive relationship with municipal expenditure, meaning that municipalities that are net receivers of population tend to increase their expenditure, while municipalities that are net ejectors of population tend to decrease their expenditures. Similarly, the variable representing the institutions of prefectural decentralization (decentralization index for the departmental level - CRD) discourages municipal expenditures (crowding out effect), while departmental GDP growth generates an economic environment that encourages greater municipal expenditures.

On average, the strength of connection or alignment reflects a mix of some "own-effort" with plenty of "dependency", creating greater alignment of expenditure to the characteristics and conditions of revenues coming from the central government rather than to the characteristics and conditions of locally generated revenues, which would always better reflect local interests and generate greater local ownership. This specific mix between own effort and dependence, the degree of misalignment and flypaper effect they generate, their evolution between the pre boom and boom periods as a result of the "natural resource tragedy", and the context set by structural constraints of poverty, culture, economic activity, demographics,

28 Following Smart (2007), experience suggests that people are more careful spending their own money (taxes paid), because they are aware of the pain of taxes and the pleasure of spending and because they feel greater ownership of the activity. Without local ownership it would seem that decentralization will not strengthen expenditure efficiency. 
geography and departmental context, together determine what might be called "the Bolivian experience" in municipal fiscal decentralization.

\section{Municipal budget constraint}

A central issue in the theory of behavior of subnational governments is their tendency to spend more than they earn, when not-own revenue is their main source of funds. This tendency is known in the literature as the soft budget problem ${ }^{29}$ or the flexible budget problem. To test the theory, model (1) is estimated using per capita fiscal balance (revenueexpenditure divided by municipal population) as the $\mathrm{Y}_{\mathrm{it}}$ variable and different individual definitions of revenue as the $\mathrm{X}_{\mathrm{it}}$ variable. Again, this is not a model of the determinants of per capita municipal fiscal balance. It is a model to establish the strength of connection or correlation between balance and different types of revenue. Control variables are included representing fiscal institutions and the municipal context of poverty, culture, geography and time.

As shown in Table 6, several breakdowns of revenues are considered, emphasizing separation between own municipal revenues (resulting in local effort) and not-own municipal revenues (resulting from national-level and foreign effort). The Table presents only the correlation coefficients of interest (Appendix 5 presents details of estimated model for 200008). The first row shows that in period 2000-2005 each Bolivian of own revenue per person was associated on average with a fiscal balance of 55 cents per person. This ratio increases to 75.3 cents in period 2006-2008 reflecting greater availability of revenues for the same or a decreasing expenditure capability in the second period. The average for the period 2000-2008 stood at 67.8 cents of balance per Bolivian of own revenues. In contrast, the row of not-own revenues shows that in period 2000-2005 each Bolivian of not-own revenues per person was on average associated with a fiscal balance of 10.2 cents per person, rising to 25.2 cents in 2006-2008 and average of 18.5 cents for the whole 2000-2008 period.

29 Empirical regularity in which an economic organization has the expectation that its deficit will be covered by other supporting organization. In the area of decentralization, a lower level of government has the expectation of being bailed-out by the central government (Kornai, 1980; Kornai, Maskin and Roland, 2003; Wildasin, 2004). Oates (2005) notes that a local government, in the presence of a flexible or soft budget constraint, will have an irresistible incentive to expand its programs and spending beyond their means. 
Table 6

Municipal correlation coefficients of the balance-revenue relationship, per capita

\begin{tabular}{|c|c|c|c|}
\hline Dependent: balance pc & $\mathbf{2 0 0 0 - 2 0 0 5}$ & $\mathbf{2 0 0 6 - 2 0 0 8}$ & $\mathbf{2 0 0 0 - 2 0 0 8}$ \\
\hline Own revenue pc & $0,550^{* * *}$ & $0,753^{* * *}$ & $0,678^{* * *}$ \\
\hline Tax pc & $0,353^{* * *}$ & $0,773^{* * *}$ & $0,748^{* * *}$ \\
\hline Nontax pc & $0,598^{* * *}$ & $0,628^{* *}$ & $0,606^{* * *}$ \\
\hline Not-own income pc & $0,102^{* * *}$ & $0,252^{* * *}$ & $0,185^{* * *}$ \\
\hline Revenue sharing pc & $0,250^{* * *}$ & $1,189^{* * *}$ & $0,461^{* * *}$ \\
\hline HDT pc & $0,536^{* * *}$ & $0,175^{*}$ & $0,155^{* *}$ \\
\hline HIPC II pc & $0,180^{* * *}$ & $0,867^{* * *}$ & $0,400^{* * *}$ \\
\hline Donations pc & 0,056 & $0,325^{* * *}$ & $0,267^{* * *}$ \\
\hline
\end{tabular}

Source: Authors' own elaboration. See Appendix 5 for details of results for the period 2000-2008.

$* * *$ Significant at *** $1 \%$; ** significant at $5 \%, \mathrm{pc}=$ per capita.

This set of results, on the one hand, contradict theory given that the sign of coefficients is consistently positive, regardless of the period and if revenues are own or not. Theory predicts negative sign when not-own revenues are greater than own because of the incentive to spend more than revenues or incentive to accumulate deficits. The problem in the case of Bolivian municipalities was their tendency to accumulate surplus due to rapid growth of not-own revenues $^{30}$ (Figure 5a) against a lower growth rate of investment expenditures in the same period, despite the substantial productivity increase of wages (Figure 5b).

Figure 5: a) Aggregated behavior of municipalities' revenues

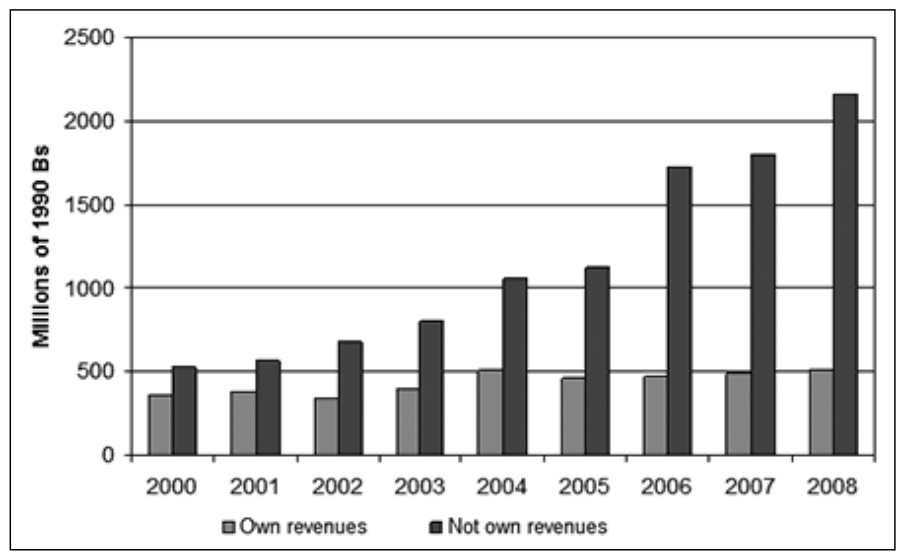

Source: Authors' own elaboration.

30 Not-own revenues grew at an annual accumulated rate of $84 \%$ in period $2000-2005$ and an additional $78 \%$ in period 2005-2008. 


\section{b) Aggregated behavior of municipalities' expenditures}

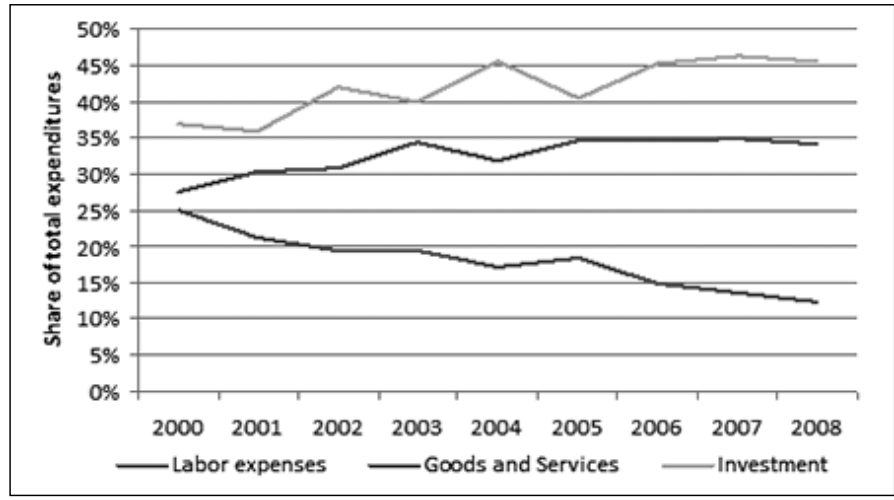

Source: Authors' own elaboration.

On the other hand, these results are consistent with theory in the context of fiscal surplus because coefficients for own revenues are consistently higher than coefficients for notown, independent of the period (except revenue sharing and HIPC in 2006-2008). That is, even though an accumulation of surplus occurs by high growth of not-own revenues, the contribution of each Bolivian of not-own revenue to surplus is significantly lower compared to the contribution of each Bolivian of own revenue (more than double in $2000-2008)^{31}$. That is, as long as there is fiscal surplus there is no emergence of the soft budget constraint problem, but the seed is there. A result that shows (again) another peculiarity of Bolivia's experience in municipal fiscal decentralization.

Following with Table 6, we observe the own revenue breakdown between tax and non-tax sources, both contribute significantly to the accumulation of surplus in 2000-2008 (tax little more than non-tax), when analyzing the behavior for the pre boom and boom periods, tax revenues have greater impact in period 2006-2008 and non-tax revenues have greater impact in period 2000-2005. This result could mean incentive to substitute one source of income by another, both own-sources, depending on the circumstances and context change.

31 Oates (2005: 361) notes that the soft budget constraint problem is a perverse fiscal behavior that cannot be solved with a simple recipe for behavior change to one responsible, because the problem is endogenous to the system itself, it induces it. Its solution requires reform in political and fiscal institutions such that the whole structures of incentives on budgetary decisions change. These institutions contain the seeds of their own destruction (Oates, 2005: 367). 
As for the four sources of not-own revenue, all contributed positively, but on average it was the revenue-sharing transfers and HIPC that had the greater incidence in accumulation of surpluses in period 2000-08. However, when analyzing their behavior during the pre-boom and boom periods, their contribution was larger in 2006-2008 than in 2000-2005. In period 2000-2005 it was transfers through IDH which contributed most to surplus, despite the fact that IDH was implemented in 2005. Again a substitution of sources appears depending on the circumstances and change in context.

\section{Incentive to own revenue generation}

Another central prediction in the theory is that different sources of not-own revenues discourage own revenue collection, also in their different sources. To test the theory, model (1) is used to estimate coefficients that establish the correlation between own and not-own revenues for the identified periods. In this case, own revenue is used as the variable $\mathrm{Y}_{\text {it }}$ and not-own as the variable $\mathrm{X}_{\mathrm{it}}$. Again this is not a model of the determinants of municipal per capita own revenues; it only shows the strength of the connection or correlation between different types of own and not-own revenues. In addition to control variables representing fiscal institutions and the municipal context of poverty, culture, also the per capita municipal fiscal balance is included in order to control for the fact that municipalities tend to operate in surplus.

Considering period 2000-2008, Table 7 presents summary of estimated correlations for two cases of interest (see Appendix F for details). Case 1 includes per capita fiscal balance as control variable and Case 2 does not. The reason is the change in magnitude of estimated coefficients (and in one case its significance) when the fiscal balance restriction is included or not. As noted above, there was a tendency for a positive fiscal balance or surplus in most municipalities, and therefore a natural disincentive to own revenue generation, which is verified with the estimated coefficients under Case $2^{32}$. However, our main interest is to verify if the trend is maintained after controlling for fiscal balance, which is equivalent to imposing a balanced budget.

32 Except for the revenue sharing variable that presents a significant positive coefficient. The latter is not a result solely of the Bolivian experience; a similar result was also found for the case of Peru by Canavire, Martínez-Vázquez and Sepúlveda (2011). The explanations suggested by these authors is that subnational governments have improved their administrative capacity to provide public services and to charge for them, in a context of growing demand and increased capacity of local payment. For the Bolivian case one must also consider the context of surplus balances and the fact that per capita operating expenses tended to be higher than per capita investment expenditure. 
Table 7

Correlation between own and not-own revenues (per capita, 2000-2008)

\begin{tabular}{|c|c|c|c|}
\hline Case 1: Including balance & Tax & Non tax & Own revenue \\
\hline Not-own Revenue & $-0,036$ & $-0,035^{* *}$ & $-0,072^{* *}$ \\
\hline Revenue sharing & 0,017 & $0,050^{*}$ & 0,066 \\
\hline HDT & $-0,032$ & $-0,032^{* *}$ & $-0,065^{* * *}$ \\
\hline HIPC II & $-0,073$ & $-0,094$ & $-0,169^{*}$ \\
\hline Donations & $-0,033$ & $-0,034^{*}$ & $-0,067^{* *}$ \\
\hline Case 2: Not including balance & Tax & Non Tax & Own Revenue \\
\hline Not-own revenue & $-0,011^{*}$ & $-0,016^{* *}$ & $-0,028^{* * *}$ \\
\hline Revenue sharing & 0,060 & $0,077^{* *}$ & $0,135^{* *}$ \\
\hline HDT & $-0,018^{* *}$ & $-0,022^{* *}$ & $-0,041^{* * *}$ \\
\hline HIPC II & $-0,038$ & $-0,071$ & $-0,111$ \\
\hline Donations & $-0,008$ & $-0,015^{*}$ & $-0,023^{* *}$ \\
\hline
\end{tabular}

Source: Authors' own elaboration. See Appendix 6 for details of results.

*** Significant at 1\%; ** significant at $5 \%$; ${ }^{*}$ significant at $10 \%$.

Under Case 1, Table 7 first row third column shows in general that each Bolivian of notown revenue induces a decrease in own revenue by 7.2 cents per person. A result consistent with theory: the opportunity to access not-own revenues discourages own revenue collection. The breakdown of not-own revenues into its various individual sources allow verification that HDT transfers and donations are the source of the effect of discouraging generation of own revenues by 6.5 and 6.7 cents per person respectively. Revenue-sharing transfers and HIPC, by not being significant, have instead a neutral effect. Continuing with period 2000-2008, when own revenues is broken down into their two tax and non-tax sources, a negative effect is verified from HDT to non-tax revenues as source of the indirect negative impact on own. This is in addition to the direct negative effect of donations on own revenues.

\section{Models of impact of municipal decentralization}

So far all models presented evaluate the internal management of municipalities with emphasis on ex ante or budgeted variables, such as fiscal revenue. This section seeks rather to assess the impact or external management of the fiscal institutions implemented, particularly on variables representing source of economic development at the municipal level. In this case, the strategy is to estimate models with emphasis on ex post explanatory variables, as are those of actual expenditure, including measures of ex post municipal fiscal expenditures, seeking to 
establish the characteristics of connection between fiscal results and impacts on economic development.

Given that from its inception municipal decentralization was conceptually designed as a compensation mechanism for the "social debt", the natural variables to study impact would be likely to improve equal opportunities and consequently reduce poverty. Education is a variable with the particular effect of improving available social opportunities (decrease inequalities) and at the same time improve available productive opportunities (improving competitiveness) and thus, through their joint and interactive effect, contribute to poverty reduction ${ }^{33}$. A necessary consideration when using the education variable to assess the impact of municipal decentralization is that, by design of fiscal institutions, the departmental level (prefectures) were to take responsibility for personnel expenditures related to education (teacher's salaries), leaving municipalities the responsibility for financing expenditure on goods and services and infrastructure-investment, also related to education and according to local needs.

The strategy for this assessment is to use net coverage rates of primary schooling, eighth grade approval rates, dropout rates and reprobation rates for primary schooling, published by the Ministry of Autonomy (2011), as dependent variables in four panel models for period 2005-2008 ${ }^{34}$. The main explanatory variables are ex post measures of municipal and prefectural decentralization expenditures ${ }^{35}$ as representative of the fiscal and political institutions of decentralization. We are interested in their statistical significance as explanatory variables or at least the significance of their correlation in addition to their direction and magnitude.

In these models the control variables are departmental per capita GDP; health and education indices contained in the Human Development Index of 2001 as the state of initial human capital development; unsatisfied basic needs in housing and services of 2001 as representative of initial poverty; proportion of indigenous population in each municipality as representative of the local culture; initial position of each municipality in terms of net migration; importance of agricultural employment in each municipality; geopolitical area to

33 This impact assessment approach is consistent with the approach of the inequality-poverty-growth triangle of Bourguignon (2002 and 2004).

34 It should be noted that only the first two education variables are part of the Millennium Development Goals.

35 The variable measuring ex post municipal decentralization (Desc.M) is defined as the ratio of municipal expenditure to central government expenditure. The variable measuring ex post prefectural decentralization (Desc.D) is defined as the ratio of prefectural expenditure to central government expenditure. 
which each municipality belongs; annual dummies and departmental capital city dummies. Estimated regressions are presented in Table 8.

In the case of the rate of net primary school coverage $(\mathrm{CNP})$, there is a positive elastic and significant coefficient for the variables representing the institutions of municipal and prefectural decentralization, both ex post. In addition, the elasticity of impact of the prefectural expenditure over coverage is 2.78 times greater than the elasticity of impact of municipal expenditure over coverage. However, neither of these two variables are significant in the case of eight grade approval rates (TT8). The initial average education attained by the municipality (iedu2001) is more important to improve $T \Gamma 8^{36}$, as well as cutting the dropout rate (TAP) and the reprobation rate (TRP). One aspect that cannot be deducted from the estimated models is how efficient was the use of decentralization resources for the educational outcomes it generates. That is, if the cost of generating an additional $1 \%$ of coverage and approving rate is reasonable or excessive. Nor can we say anything about whether the cost of the education quality acquired by the beneficiaries is reasonable or not.

Table 8

Impact of fiscal decentralization on primary education (2005-2008)

\begin{tabular}{|l|c|c|c|c|}
\hline \multicolumn{1}{|c|}{ Variables } & CNP & TT8 & TAP & TRP \\
\hline In(Desc.M) & $1,714^{* * *}$ & 0,401 & $-0,121$ & 0,035 \\
& $(0,402)$ & $(0,467)$ & $(0,191)$ & $(0,088)$ \\
\hline In(Desc.D) & $4,769^{* * *}$ & $1,929^{*}$ & $-0,694^{* *}$ & $-0,411^{* *}$ \\
& $(1,032)$ & $(1,095)$ & $(0,303)$ & $(0,180)$ \\
\hline In(PIBpc D) & $-3,337^{* * *}$ & $-2,530$ & $-0,723$ & 0,037 \\
& $(1,222)$ & $(1,907)$ & $(0,486)$ & $(0,366)$ \\
\hline isalud2001 & $-0,610^{* * *}$ & $0,243^{* *}$ & 0,016 & $-0,003$ \\
& $(0,164)$ & $(0,105)$ & $(0,024)$ & $(0,016)$ \\
\hline iedu2001 & $0,394^{* * *}$ & $0,754 * * *$ & 0,006 & $-0,049 * * *$ \\
& $(0,148)$ & $(0,105)$ & $(0,022)$ & $(0,017)$ \\
\hline NBI2001 & $0,246^{* * *}$ & $-0,096$ & $-0,022$ & $-0,031^{* * *}$ \\
& $(0,095)$ & $(0,071)$ & $(0,017)$ & $(0,009)$ \\
\hline \%Indigenous 2001 & $-0,072^{*}$ & 0,046 & $-0,001$ & $0,015^{* * *}$ \\
& $(0,041)$ & $(0,032)$ & $(0,006)$ & $(0,004)$ \\
\hline
\end{tabular}

36 Similar conclusions were obtained (with higher elasticities) when panels were estimated for the longer period 2001-2008, but considering only information on net coverage of primary schooling and eighth grade approval rate, published by UDAPE and UNDP in the context of MDGs monitoring. 


\begin{tabular}{|l|c|c|c|c|}
\hline \multicolumn{1}{|c|}{ Variables } & CNP & TT8 & TAP & TRP \\
\hline Agropec2001 & $-0,212^{* *}$ & $-0,088$ & $0,038^{* *}$ & 0,001 \\
& $(0,090)$ & $(0,059)$ & $(0,015)$ & $(0,009)$ \\
\hline Migration 2001 & $-0,117^{* *}$ & $-0,101$ & $0,024^{* *}$ & 0,004 \\
& $(0,053)$ & $(0,086)$ & $(0,011)$ & $(0,004)$ \\
\hline CNP & & $0,637^{* * *}$ & $0,043^{* * *}$ & $0,034^{* * *}$ \\
& & $(0,035)$ & $(0,011)$ & $(0,007)$ \\
\hline TT8 & $0,359^{* * *}$ & & $-0,039^{* * *}$ & $-0,020^{* *}$ \\
& $(0,026)$ & & $(0,010)$ & $(0,008)$ \\
\hline TAP & $0,419^{* * *}$ & $-0,440^{* * *}$ & & 0,011 \\
& $(0,106)$ & $(0,138)$ & & $(0,029)$ \\
\hline TRP & $0,515^{* * *}$ & $-0,482^{* * *}$ & 0,017 & \\
& $(0,116)$ & $(0,147)$ & $(0,046)$ & $3,250 * *$ \\
\hline Constant & $69,418^{* * *}$ & $-34,550^{* * *}$ & $5,928^{* *}$ & $(1,563)$ \\
\hline Observations & $(13,455)$ & $(10,991)$ & $(2,601)$ & 1.233 \\
Groups & 1.233 & 1.233 & 1.233 & 313 \\
R2 intragroup & 313 & 313 & 313 & 0,615 \\
R2 intergroup & 0,252 & 0,160 & 0,207 & 0,495 \\
Overall R2 & 0,642 & 0,815 & 0,210 & 0,574 \\
Theta & 0,613 & 0,752 & 0,210 & 0,308 \\
\hline
\end{tabular}

Source: Authors' own elaboration. Estimated by random effects model; however, when Tetha is closer to zero becomes a fixed effects model. All regressions include annual dummies and department capital city dummies not reported due to space restrictions. Numbers in parentheses are robust standard errors.

$* * *$ Significant at $1 \%$; * significant at $5 \%$; ${ }^{*}$ significant at $10 \%$.

In the case of TAP and TRP a significant negative coefficient is verified for the ex post fiscal expenditure variable at the prefectural level, which represents the institutions of prefectural decentralization. That is, this expenditure does have the ability to lower these rates, with greater impact on dropout rate than on the TRP, although in both cases inelastic. Instead, the variable of municipal expenditure that represent the institutions of municipal decentralization, is not significant in any of the two cases, i.e. there is no evidence that it helps to reduce these rates. It should be noted that these rates (TAP and TRP), that are not part of the MDGs, have characteristics that make them more demanding for reduction, especially TRP because it responds to more qualitative aspects of education. Indeed, the MGD goals of coverage rate and approving rate are quantitative, not qualitative (quality).

The models suggest that quantitative and qualitative targets can be improved with increasing expenditure at the prefectural level (salaries to teachers that are administered 
and defined in practice at the national level anyway, given the former close link between prefectures and that level). In contrast, with expenditure at the municipal level, which is mainly for infrastructure, it is possible to improve the coverage rate but not the approval rate and less so the dropout and reprobation rates, which require the handling of more qualitative aspects. Qualitative goals are much harder to achieve and usually require a higher degree of participation, involvement and ownership of goals by the local beneficiaries, i.e. dominance towards local alignment, which was not observed in the Bolivia's decentralization experience in general, particularly at the municipal level.

\section{Incentives in fiscal decentralization at the intermediate level}

In the case of the prefectures ${ }^{37}$, a fiscal decentralization analysis cannot be fully implemented because at this level, rather than decentralization, what existed up until 2006 was a deconcentration scheme. Unlike municipalities, prefectures didn't have own revenues from taxes, and their own revenue was limited to the sale of goods and services, fees, rights and other revenues such as fines and interests. Thus, the share of own revenues in total revenue is very small, and its importance was declining over time. For this reason it is clear that the alignment of prefectures was towards the interests of the national government.

This context raises three issues to be considered: i) since the prefectures' revenues depended almost exclusively on the transfers from the national government, it seems reasonable to propose the hypothesis that these transfers have contributed to discourage a culture of tax payment; ii) failing to cover expenditures with own revenues is the basic characteristic of an administration with soft budget features, leading to the complications it implies iii) given that the most significant transfers come from the surplus generated by the exploitation of hydrocarbon resources, they absorb the price volatility of those resources, creating revenue risk and uncertainty. This section seeks to verify the existence of symptoms of the first and third issues. For the second issue, significant positive balances were observed for prefectures in the period of study because of the increasing accumulation of transfers received from royalties and other (national-level) hydrocarbon taxes, making it difficult to isolate possible symptoms of soft budget in this context.

37 As mentioned before, prefectures became departmental governments (Gobernaciones) after the new National Constitution of January 2009 was enacted. Because the period of analysis corresponds to the prefecture era (under another legal framework), in the rest of the document prefectures are used as the unit of analysis. In some cases we refer to them as former prefectures, to highlight the fact that they ceased to exist. 
Unlike the analysis of municipalities, where the total number is large enough, in the case of the intermediate level the number is reduced to nine prefectures (one for each department). That is why it was necessary to extend the number of periods (years) merging different data sources, taking care at all times that the different sources are consistent in their definition and size units. The two main data sources used to obtain information on revenue and expenditure of prefectures were: i) the ForoDAC Database for the 2000-2008 data series, and ii) the publication "Economic Statistics of the Decentralization Process", prepared by the Ministry of Planning and Sustainable Development, for the 1996-1999 data series. The disaggregation of the latter is much less detailed than that presented by the ForoDAC, which in some cases has limited the model building. Other data sources consulted were UDAPE, INE, Ministry of Economy and Finance and the National Tax Service. The final data set runs from 1996 to 2008 for some variables and from 2000 to 2008 for others.

For the different estimates presented in this section, the following definition of accounting variables were used, expressed in real terms (1990 Bs.):

1. Total revenue, defined as the sum of own and not-own sources of revenue;

2. Own revenues: include non-tax current revenues, revenues from sale of goods and services, interest, property rents and own capital revenues. Notice once more that unlike the case of municipalities, prefectures themselves don't have own-tax revenues;

3. Not-own revenues: include royalties, current transfers, capital transfers and donations;

4. Current transfers can originate from the private sector, public sector, external sector or other. Public sector transfers may in turn come from hydrocarbon taxes (IDH, IEHD), subsidies or grants, the solidarity municipal fund or the Departmental Compensation Fund;

5. Donations: these may be current or capital donations;

6. Expenditures: include all current and capital expenditures;

7. Department GDP;

8. National-domain tax collection (NDTC) in each department, geographically speaking: comprising the value added tax (VAT and Complementary Regime to Value Added Tax RC-IVA), the Transactions Tax (IT), the Corporate Income Tax (IUEand Complementary Regime to Corporate Income Tax RC-IUE), and the Specific Consumption Tax (ICE);

9. International oil price. 
The following control variables were also used:

i. Municipal and departmental decentralization variables. These are the same as those used in the analysis of municipal decentralization.

ii. Poverty: several poverty indicators were considered, including the UBN, the poverty head count ratio and other indicators of the FGT family.

iii. Geographical Variables: There were two main distinctions: i) by geographical area (highlands, valleys, plains), and ii) whether or not the department belongs to the nation's central economic axis (La Paz, Cochabamba, Santa Cruz).

iv. A time variable, to capture trends in the different dependent variables.

v. Period dummy. This variable seeks to distinguish the 1996-2005 period from the 2006-2008 period for two reasons: First, as will be shown, the period 2006-2008 was characterized by a significant growth in revenue, which, as in the case of municipalities, is referred to as the boom period. Second, in 2006 there is a change of regime from E2 to E1, were prefectural authorities begun to be elected by direct vote of local citizens.

vi. 2008 dummy. In some cases this variable is used to distinguish the year 2008 from the rest of the series, because in this year a new distribution of IDH was applied.

In order to provide some information based on the overview of the behavior of prefectures, here are some stylized facts. It was mentioned that revenue decentralization at the municipal level was larger than at the prefectural level (the latter was practically non-existent), yet expenditure decentralization at the prefectural level was larger compared to the municipal level (see Appendix 3). This is an important design feature of fiscal and political institutions of implemented decentralization.

As for the structure of revenues of all former prefectures, Figure 6a shows that by design of fiscal institutions it is the national public policy ${ }^{38}$ transfers that have been their main source of revenue, highlighting the extent of dependence of the prefectural level to this source of revenues as opposed to own. Figure $6 \mathrm{~b}$ shows that the dominant source of revenue throughout the decade were subsidies from the central government, but in the second half of the decade revenues increased significantly due to royalties and IDH. Subsidy transfers come from the National Treasury and is administrated by the central government though it figures in the

38 Includes royalties, subsidies or grants, IDH, IEHD, municipal solidarity fund, departmental compensation fund and other transfers, which are all defined at the central government level as part of national public policy. 
prefectures accounts. It is directed to salaries of teachers and medical doctors (Espada, 2011). The rest of transfers originate almost entirely on the different hydrocarbon revenue sources.

Table 9 shows average values of the prefectures' revenues for the years 1996-2008 at constant prices. These revenues have more than doubled over the considered period, even more than tripled when considering the simple average. The average, weighted by the respective population of each department, grew from 143.35 to 360.35 and the median from 161.79 to 421.13 . As mentioned above, the largest jump occurred between 2005 and 2008.

Figure 6: a) Prefectures' revenues

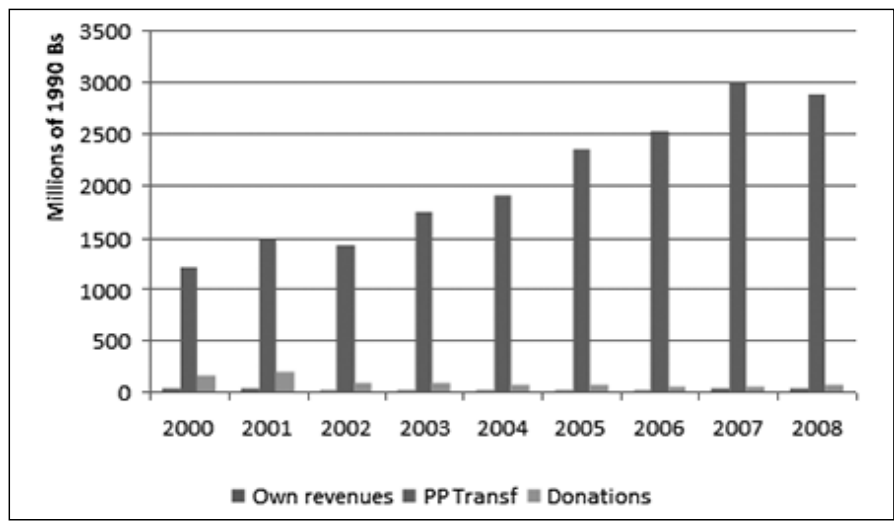

Source: Authors' own elaboration

b) Public policy transfers

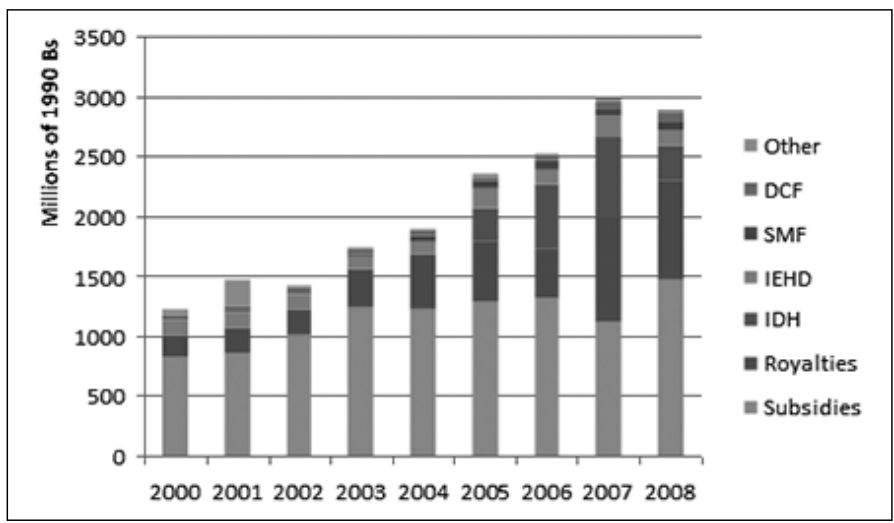

Source: Authors' own elaboration 


\section{Table 9}

Evolution of average revenue measures of prefectures (1990 Bs.)

\begin{tabular}{|l|c|c|c|c|c|c|c|}
\hline \multicolumn{1}{|c|}{ Year } & $\mathbf{1 9 9 6}$ & $\mathbf{1 9 9 7}$ & $\mathbf{1 9 9 8}$ & $\mathbf{1 9 9 9}$ & $\mathbf{2 0 0 0}$ & $\mathbf{2 0 0 1}$ & \multicolumn{1}{c|}{$\mathbf{2 0 0 2}$} \\
\hline Simple mean & 183,77 & 216,89 & 221,80 & 233,14 & 251,26 & 307,19 & 254,27 \\
\hline Weighted mean & 143,35 & 159,05 & 159,47 & 156,09 & 169,79 & 205,19 & 186,30 \\
\hline Median & 161,79 & 182,23 & 172,85 & 184,32 & 204,14 & 175,66 & 219,32 \\
\hline \multicolumn{1}{|c|}{ Year } & $\mathbf{2 0 0 3}$ & $\mathbf{2 0 0 4}$ & $\mathbf{2 0 0 5}$ & $\mathbf{2 0 0 6}$ & $\mathbf{2 0 0 7}$ & $\mathbf{2 0 0 8}$ & \\
\hline Simple mean & 297,93 & 379,90 & 508,06 & 657,68 & 792,28 & 594,86 & \\
\hline Weighted mean & 225,66 & 241,01 & 295,52 & 365,04 & 370,06 & 360,35 & \\
\hline Median & 226,45 & 252,49 & 322,85 & 455,32 & 322,98 & 421,13 & \\
\hline
\end{tabular}

Source: Authors' own elaboration based on data from ForoDAC and the Ministry of Planning and Sustainable Development.

Note: The simple mean refers to average revenue of prefectures without considering its population, while the weighted average uses Departmental population as specific weights.

The fact that the simple average is consistently higher than the weighted average, suggest that prefectures of the less populated departments had larger per capita revenues than those from the more populated departments. This is the case of Tarija and Pando. The first is the main hydrocarbon producer, which receives a large share of its revenues from royalties; and the second, a non-hydrocarbon producing department, receives its revenues primarily from the distribution of hydrocarbon taxes (tax-sharing). These two cases are best illustrated in Figure 7, which shows the evolution of per capita income by prefecture. Triangles represent Pando and squares represent Tarija. Higher values correspond to Pando, reaching per capita revenue of nearly Bs. 3,500 in 2007, more than seven times the revenue of other prefectures which were below Bs. 500 per capita. 
Figure 7: Per capita revenues of prefectures

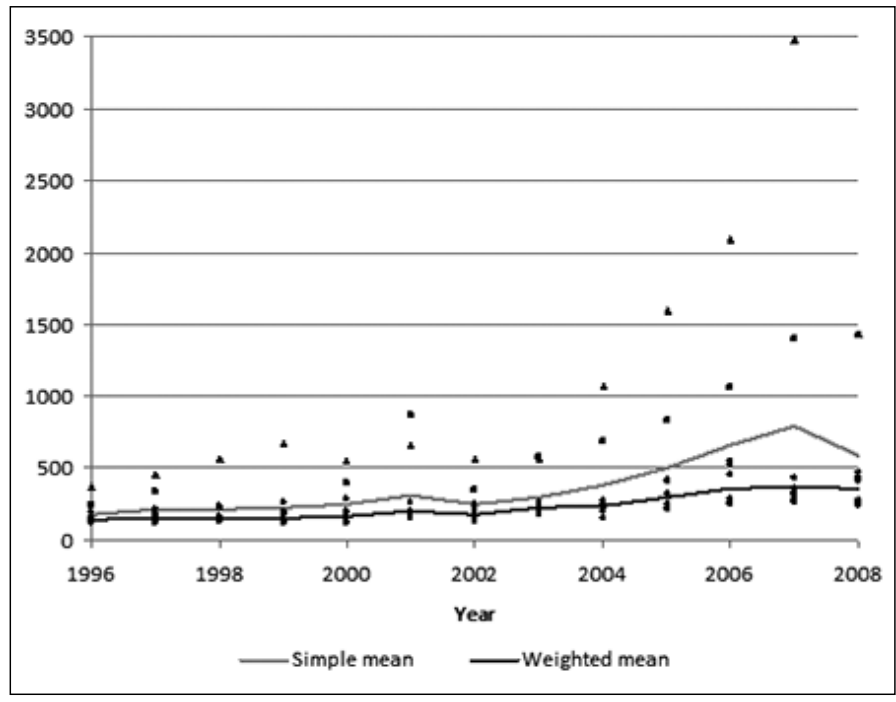

Source: Authors' own elaboration

\section{Model of tax contribution effort}

For the sake of clarity we repeat that the main difference between prefectures and municipalities is that the former did not have revenues from own taxes. However, it is within departments that national-domain taxes are collected, geographically speaking. It seems important to analyze the National Domain Taxes collection (NDTC ${ }^{39}$ ), in each Department given that these are paid by departmental taxpayers and used primarily to finance national expenditures, opening the possibility to generate a disincentive to pay them (hypothesis), because the taxpayer does not perceive directly the fruits of his effort and dislikes the distribution of that money among other departments with less tax-effort.

The analysis was limited to the four main national-domain taxes collected in all departments: the value added tax (IVA domestic market and RC-IVA), the corporate income tax (IUE and IUE-RE), the transactions tax (IT), and the specific-consumption tax (ICE). Because the different hydrocarbon-based taxes return to departments through transfers,

39 An analysis of this type was made previously in Villarroel-Böhrt (2005), which evaluates the constraints (for example, the discrepancy between the legal home of a taxpayer and the place where the economic activity takes place) to carry out a process of this nature. A similar approach is also used in Jin et al. (2005) to analyze the case of China. 
they are not considered in this section. Neither are the customs tariffs because of the lack of relationship between the place where they are collected (usually border points) and the destination department.

Figure 8a shows the evolution and composition of national domain tax revenues for the years 2000-2008, in millions of 1990 Bolivians. The graph shows an increase in total tax collection during the analyzed period, with the two largest sources being IVA and IUE, the latter having experienced the highest growth. Figure $8 \mathrm{~b}$ compares National Domain Tax Collection (NDTC) with current transfers received by the prefectures from the national level, including royalties and subsidy transfers ${ }^{40}$ in millions of 1990 Bolivians. It is noted that national domain tax collection and transfers received by departments have evolved similarly during the considered period. A significant decrease in transfers can also be observed in 2008, due to the new redistribution of the IDH resources ${ }^{41}$.

Figure 8: a) National domain tax collection

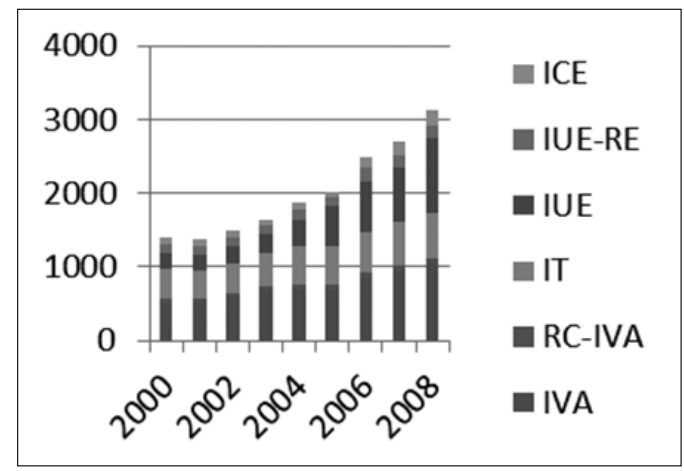

Source: Own elaboration

40 It was already mentioned that subsidy transfers consist primarily of payments of wages and salaries to teachers and medical doctors. Although they are funded by the National Treasury (TGN), these are accounted for through a departmental account.

41 By Supreme Decree No. 29322. 
b) NDTC and transfers to prefectures

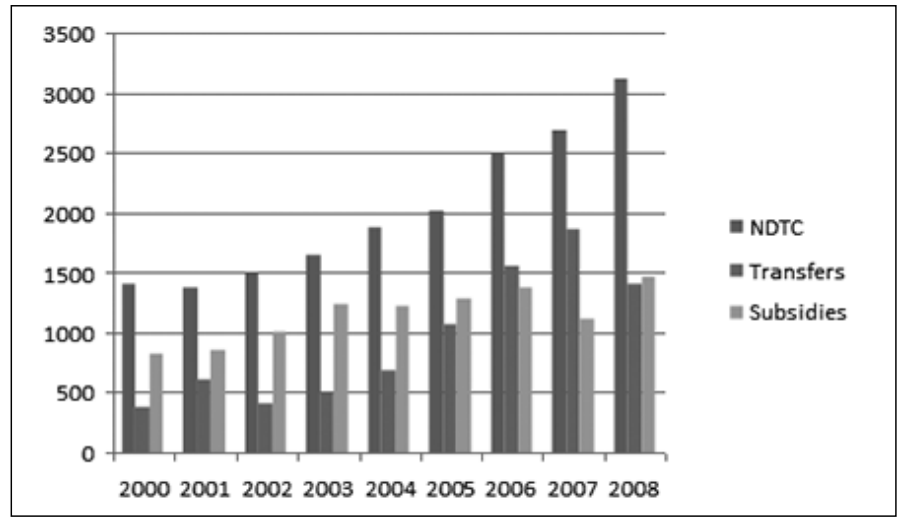

Source: Own elaboration

For the analysis at the department level, it is considered the ratio of the revenues received by the prefectures through national level transfers (including subsidies), and the NDTC for each department. Figures $9 \mathrm{a}, 9 \mathrm{~b}$ and $9 \mathrm{c}$ show these ratios for all nine departments, grouped as follows: Group 1, for the departments where this ratio was higher than 10 in any year; Group 2, for the departments where this ratio was less than 10 but greater than 2; and Group 3, for the departments where this ratio was less than 2 .

Figure 9: a) Group 1

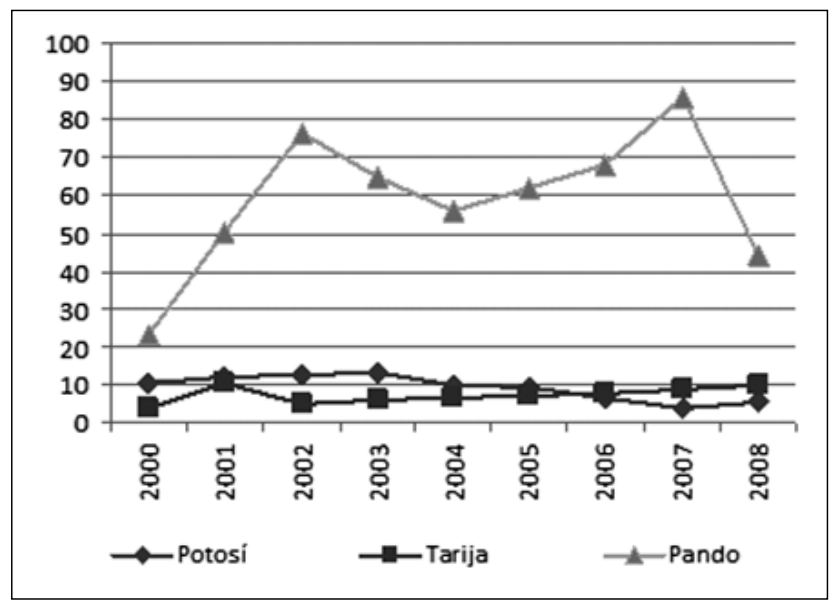

Source: Own elaboration 
b) Group 2

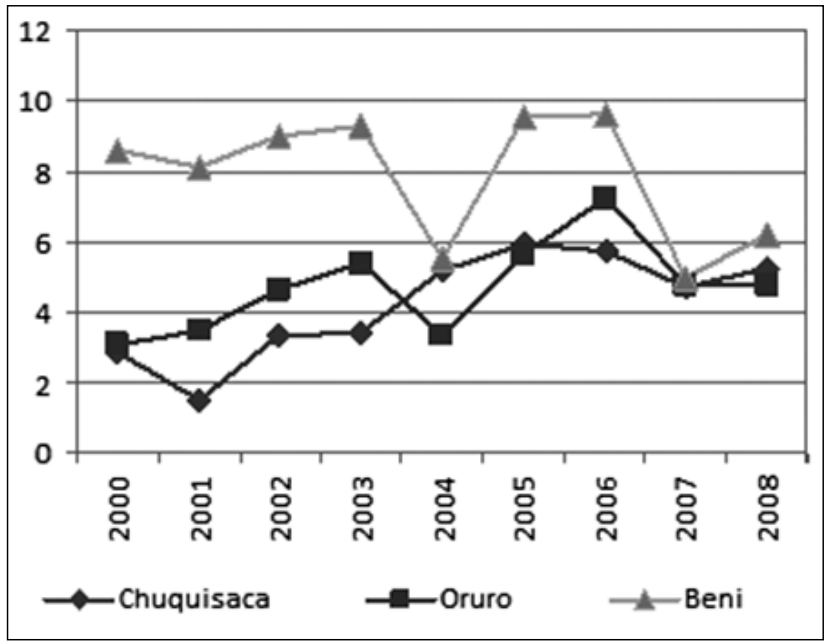

Source: Own elaboration

c) Group 3

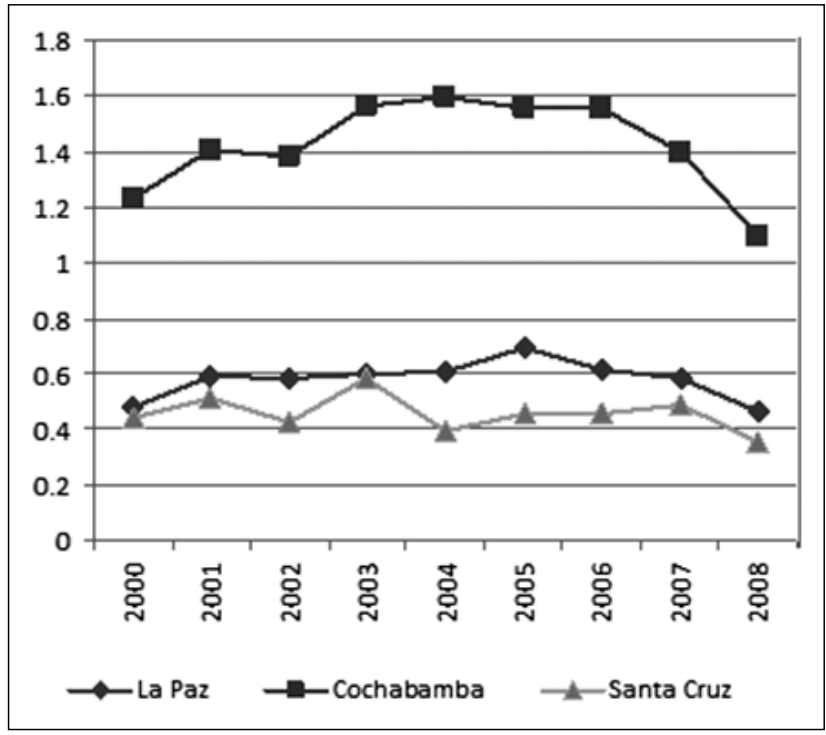

Source: Own elaboration 
The graphs show that most departments received an amount of transfers much greater than the national taxes generated in their territory, the exceptions being La Paz and Santa Cruz, where the received transfers were about half of the collected taxes in those departments. In the case of Cochabamba, the ratio ranged between 1 and 1.6 in the studied period.

While tax collection is of national domain and not distributed directly to prefectures, the large differences shown in the graphs might signal to most contributing departments, who can deduce that their territories generate more than what they perceive, which could cause a disincentive to the effort for generating tax contributions. On the other hand, departments that receive greater revenue, through their prefectures, in relation to what is generated in their territory are not motivated to collect taxes, because they know that their revenue come from the taxes collected in other territories anyway. These assumptions deserve further quantitative analysis. Next section presents the correlations between the collection of the different taxes with the different transfers received by the prefectures from the national level.

The model of tax collection effort consists in finding the correlations between the per capita tax collection and the different sources of not own revenues of prefectures, controlling for the other department's variables. For each i and each year:

$$
\text { collection }=\alpha x+\sum_{i} \beta_{i} z_{i}
$$

Where $x$ is a not-own revenue, $\alpha$ is the parameter to be estimated; $z_{i}$ are the control variables and $\beta_{i}$ are their respective coefficients.

For this model, the panel is of size $\mathrm{N}=9$ and $\mathrm{T}=9$ ( 9 individuals and 9 periods). In the panel data literature, a panel is considered "short" when it has relatively many individuals and few periods, and a panel is considered "long" when the number of periods exceeds the number of individuals. Considering the first case, an appropriate estimation method would be for panel data with random effects and standard errors corrected for cluster, as in the case of municipalities. In the second case, it would be appropriate to introduce an auto-regressive process (AR) in the errors. Since the data have as many individuals as periods, correlations were estimated using both methods, abbreviated with the letters CEC for the method that makes error corrections with cluster and AR1 for the method introducing an AR1 error 
process $^{42}$. Table 10 shows estimated coefficients for parameters $a$ for the IVA tax model, which includes the domestic IVA and RC-IVA. The data on collected taxes as well as the revenue variables are expressed in per capita income and constant values terms.

In the $\mathrm{CEC}$ case, the number of controls had to be limited so that the number of estimated coefficients did not exceed the number of clusters, which can cause calculation problems in some statistics. While some coefficients change in value and degree of significance from one model to another, there is clear consistency in the negative correlation between IVA revenues and royalties, regardless of the estimation method and change in the control variables used. The estimated coefficient on both methods indicates that for every additional Bolivian of royalties given to the prefecture, there is a decrease of 9.1 cents in the IVA tax collection.

Table 10

Correlation coefficients per capita Income Tax department

\begin{tabular}{|c|c|c|c|c|c|c|}
\hline CEC & Model 1 & Model 2 & Model 3 & Model 4 & Model 5 & Model 6 \\
\hline Royalties pc & $-0,091 * *$ & & & & & \\
\hline IDH pc & & $-0,014^{* *}$ & & & & \\
\hline IEHD pc & & & $-0,04 * *$ & & & \\
\hline Comp. Fund. Pc & & & & 1,778 & & \\
\hline Other transf. Pc & & & & & 0,003 & \\
\hline Donations pc & & & & & & 0,221 \\
\hline \multicolumn{7}{|l|}{ AR1 } \\
\hline Royalities pc & $-0,091 * * *$ & & & & & \\
\hline IDH pc & & $-0,008$ & & & & \\
\hline IEHD pc & & & $-0,009$ & & & \\
\hline Comp. Fund. Pc & & & & $1,354 * *$ & & \\
\hline Other transf. Pc & & & & & 0,007 & \\
\hline Donations pc & & & & & & 0,167 \\
\hline
\end{tabular}

Source: Own elaboration. See Appendix 7 for details of estimates.

*** Significant at $1 \%, * *$ significant at $5 \%$.

With regard to the correlation between this tax and the IDH or IEHD transfers, the first estimation method shows significant and negative results. By introducing an AR1 process,

42 In long panels emphasis is to exploit the data both ways, its variability over time and between individuals. Using variables in levels (possibly non-stationary) and not differenced (stationary) more attention has been paid to their long-term or structural effects rather than the short term. Individual year dummies are introduced to capture the effect of time and thus reduce potential spurious relationships. The estimated equation is assumed to be a longterm equilibrium relationship; however the robustness of this assumption must be verified with a longer time series. 
coefficients are still negative, but not significant (P-value equal to 0.117 for IDH). The same correlation analysis was performed for IUE, ICE and IT, but in all cases all correlations were not found significant for any of the estimation methods. The fact of finding a significant results in the IVA case may be due to characteristics of this tax that make it easier to evade, which would be consistent with the hypothesis that transfers don't generate a tax payment culture.

\section{Model of correlation between prefectures revenues and gas prices}

As it was already mentioned, most prefecture revenues come from the surplus generated by exploitation of hydrocarbon natural resources. The hypothesis is that this situation creates high risk due to the price volatility of these resources ${ }^{43}$. In recent years, revenues from hydrocarbon natural resources have increased significantly because of the high natural resource price, and also because the export volumes have constantly increased. Figure 10 shows the evolution of oil prices and natural gas export volumes.

Figure 10: Exported volume of natural gas and international oil price

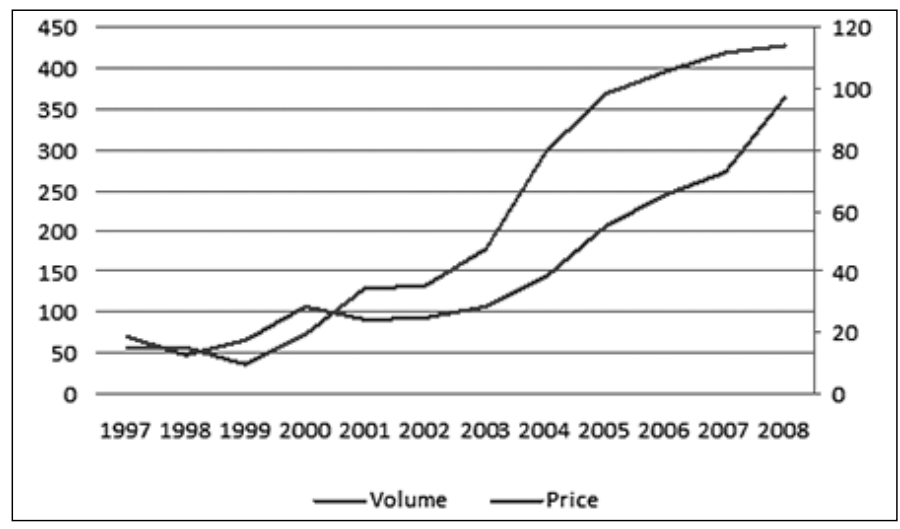

Source: Own elaboration

Both, volumes of natural gas exports (left scale, in billion cubic feet) and oil prices (right scale, in dollars per barrel) increased steadily over the period of study. This explains the prefectures revenue increase, but also highlights the dependence of these revenues on the exported quantities and the natural gas price. Since natural gas prices respond to changes in oil

43 Gas prices for export to Argentina and Brazil are determined quarterly using a formula that includes fuel oil prices, which are closely linked to international oil prices. 
prices, it is relevant to analyze to what extent a change in the oil price can affect the prefectures' revenues.

Table 11 presents the results of the estimated correlations between the different sources of prefectures revenues and oil prices (in dollars per barrel). In general there is a strong correlation between the different revenues and the price of oil. A one dollar increase in the price of oil per barrel, is related to an increase of more than two million Bolivians in total revenues of prefectures (column 1). Considering total per capita revenue (column 2), the variation over this indicator is 7 Bolivians. Columns 3 and 4 show the correlation between oil prices and per capita royalties, in total and per capita values respectively. Columns 5 and 6 show the correlation between oil prices and revenues from IEHD and IDH together, in total and per capita values respectively.

Table 11

Correlation coefficients between income and oil prices

\begin{tabular}{|l|c|c|c|c|c|c|}
\hline & $\begin{array}{c}\mathbf{1} \\
\text { Ing. total } \\
\text { (thousands } \\
\text { of Bs.) }\end{array}$ & $\begin{array}{c}\mathbf{2} \\
\text { Ing. total pc } \\
\text { (in Bs.) }\end{array}$ & $\begin{array}{c}\text { Royalities } \\
\text { (thousands } \\
\text { of Bs.) }\end{array}$ & $\begin{array}{c}\mathbf{4} \\
\text { Royalities } \\
\text { pc } \\
\text { (in Bs.) }\end{array}$ & $\begin{array}{c}\mathbf{5} \\
\text { Ing. hidroc. } \\
\text { (thousands } \\
\text { of Bs.) }\end{array}$ & $\begin{array}{c}\text { Ing. hidroc. } \\
\text { pc } \\
\text { (in Bs.) }\end{array}$ \\
\hline $\begin{array}{l}\text { Petroleum } \\
\text { Price }\end{array}$ & $2.271,2^{* * *}$ & $7,118^{* * *}$ & $838,9^{* * *}$ & $2,108^{* *}$ & $1.451,2^{* * *}$ & $6,071^{* *}$ \\
\hline
\end{tabular}

Source: Own elaboration. See Appendix 8 for details of estimates.

$* * *$ Significant at $1 \%$; $*$ significant at $5 \%$ and $*$ significant at $10 \%$.

The steady increase in oil prices had a positive effect on prefectures revenues. Furthermore, the export volumes of natural gas in the last decade were steadily rising, which increased even further the revenues originated in this economic sector. However, this double benefit (increase in export volumes and higher prices) also introduced a double risk for the department revenues. First, export volumes cannot increase indeterminately over time, natural gas is a non-renewable resource and the reserves are limited. Furthermore, export volumes are conditioned to the needs of buyers. Moreover, the price at which natural gas is sold is closely linked to the price of oil, which introduces another risk factor given its volatility. 


\section{Conclusions and final comments}

The conceptual framework presented in the second section identified two areas of application of the Second Generation Fiscal Federalism approach to the analysis of Bolivian decentralization: (1) understanding the institutions of decentralization as a problem of choice among a set of decentralization policy options, where any combination of variants gives rise to a particular reality or scenario, and (2) the existence of performance evaluation criteria common to all reality or scenarios, based on identifying incentives implicit in those institutions and the outcomes or behavior to which they give rise. The same section shows the application of that framework to the case of Bolivia, which helped to identify the policy options summarized in Table 2, which determined the structural characteristics of the institutional design of Bolivian decentralization and its evolution. The following sections presented instead application of the evaluation criteria to the identified decentralization institutions, with an emphasis on fiscal institutions.

The goal of the "top-down" decentralization implemented was to contribute to the improvement of poverty and social inclusion indicators. In terms of results achieved the study only evaluates the impact of ex post expenditure decentralization of municipalities and prefectures on education indicators for the period 2005-2008 (coverage rate, completion rate, dropout rate and failure rate). A favorable impact is found, significant and elastic, for the net rate of primary schooling coverage. In addition, the ex post expenditure decentralization of prefectures had favorable impact on the eighth grade completion rate, dropout rate and failure rate in primary schooling. The ex post expenditure decentralization of municipalities did not present direct impact on these variables but indirectly through its positive impact on the coverage rate.

It is noted that these results don't say anything about whether the unit costs per unit of achieved goal is reasonable or not, against the alternative without decentralization or a different design for the institutions of decentralization. Also, while coverage and completion rates are part of the Millennium Development Goals, dropout and failure rates are not, the latter being much more demanding in terms of quality of education, on which not much is known. In this direction, the estimated models suggest that quantitative goals can be improved with increasing subnational spending under the current institutional design. However, the fact that after nearly two decades of decentralization, progress in education continue to be measured in terms of sixth and eighth grade indicators, rather than say 12 years of education, shows that progress in 
education is still modest compared to the human capital transformation the country needs. More aggressive quantitative targets and especially quality education goals probably require a higher degree of involvement and ownership by local beneficiaries, i.e. dominance toward local alignment, which has not been observed in the Bolivian decentralization experience in general and municipal decentralization in particular.

Regarding performance evaluation of the institutions of decentralization from the perspective of their implicit incentives, the main findings were:

(1) For municipalities and the entire pre boom (2000-2005) and boom (2006-2008) periods analyzed, a positive and significant correlation was found between expenditures and own revenues, but less than with not-own revenues. Under the second generation approach this implies dominance of alignment of municipal governments towards the interests and policies from the central government rather than to strictly local interests, in fact postponing them. While in 2000-2005 this alignment was already in place, however it was not excessive. In contrast, in 2006-2008 this situation changes with the rise of dominance in the alignment of expenditure towards central government, especially due to the effect of Direct Hydrocarbon Tax (IDH) in the increase of transfers. This may well have resulted, not only because decentralization was implemented "top-down" but because initial local capacities were weak or nonexistent, which was precisely what needed to be changed, especially in the less urban and rural areas, given high dispersion and heterogeneity among locals. The slow progress in education also suggests modest changes of this reality.

Moreover, under the first generation approach, the same result is non-other than the flypaper effect. This is an old theme in the literature referred to the observed regularity that subnational governments tend to spend not-own revenues, resulting from the effort of others (transfers), much faster than own revenues resulting from local effort. This behavior results from the distorting effects of the increasing dominance of transfers in municipal revenues, because locals don't know and don't internalize the costs of their procurement by the central government. Indeed, for the subnational government the received transfers are basically free ex ante and ex post: (i) Ex ante because subnationals don't pay the central government for the administrative and political costs of tax collection and its distribution. Once subnationals receive their transfers they only internalize the costs of budget execution, from planning to their disbursement, monitoring and accountability; (ii) Ex post because subnationals don't pay the central government or society at large for the costs of total or partial failure in achieving the objectives or social goals. Strictly speaking, meeting a quantitative education target (for 
example, a net enrollment or completion target) can very well be accompanied by a partial or even complete failure of qualitative results (for example, passing a minimum knowledge standard test).

2) For municipalities and the entire period of study (2000-2008), the correlation of fiscal balance with own revenues is positive and higher than correlation with not-own revenues, in a context of fiscal surplus dominance. Under the first-generation approach, the fiscal surplus is not a result of internal efficiency but an imbalance due to excessive revenues and low spending capacity (excessive revenues occurred mainly in the boom period). Under the second-generation approach, own revenues contribute much more to balance than notown, also more so in the boom period than in the pre boom, reflecting a soft budget problem but in a context of surplus. That is, the problem of soft budget constraint, which is central to the second generation approach, is not a problem in the Bolivian case due to the increasing accumulation of fiscal surpluses (not binding), however, it is there as seed to deficit incentive to operate in the future, particularly at a time of major economic recession.

(3) For municipalities in the analyzed period (2000-2008), a negative relationship between own and not-own revenues was verified, i.e. a disincentive to the generation of own revenues as transfers increased (disincentive to the culture of local tax payment or from the perspective of public goods, disincentive to the culture of local contribution). The disincentive was not as important during the pre-boom than during the boom period. This outcome is a result of institutional design. Transfers were the main source of financing of municipalities, generating dependency and disincentive to effort and other local distortions. Initially, it was the revenue sharing (coparticipación tributaria) and debt relief transfers (HIPC) that dominated, but later the IDH transfer was dominant, which in turn is dependent on international oil prices. While transfers are necessary and their increase good news, in their practical implementation these should have been tied to local contribution goals (tax and non-tax), regardless that in most cases these might have been relatively modest compared to the magnitude of transfers, because that would maintain the culture of local contribution. However, this requirement contrasts with the fact that on average most municipalities have persistent surpluses, so there was no need for greater revenues and the proportional decrease of own revenues was not missed. However, when the surpluses disappear in a major economic recession, reversing the behavior of low local contribution will be difficult. This is why the current not committed surplus of municipalities should go to an investment fund for a rainy day, so that in the present there would be need to raise local contributions. 
(4) In the case of the former prefectures (governorships now) and for the entire period of study (1996-2008), their revenues came from different types of transfers, as by design they had no access to own taxes. For this reason, alignment of their expenditure toward the central government was predominant and, therefore, misalignment to strictly local interests. As transfers are basically $100 \%$ of prefectural revenues, an overspending tendency would be expected and, therefore, a tendency to the soft budget problem. This issue was not verified because prefectures showed rather a tendency to surplus, not by their own effort or internal efficiency but because of excessive revenues resulting from the continuous and automatic increase of some of the transfers, especially those originating in the hydrocarbon sector.

(5) Given the characteristics of the institutional framework of fiscal decentralization at the prefectural level, were received transfers originate from national level collection of taxes and royalties, an attempt was made to verify if such transfers generated implicit incentives, positive or negative, toward tax payments of national domain. The hypothesis was that transfers do not encourage a culture of tax payment (regardless of the level of dominion), in those departments that generate more national taxes than transfers received via their prefectures, as in those receiving more transfers than the national taxes they generate. Specifically, we looked for correlations between the different types of transfers received (royalties, IDH, IEHD, compensation fund and other transfers and donations) and the different types of national taxes collected in each department (IVA, IUE, ICE and IT). As a result only a negative and significant correlation was found (disincentive) between royalty transfers and the IVA collection. Correlations from all other combinations were not found statistically significant, neither positive nor negative, highlighting statistical independence between the two types of variables.

(6) It was also verified that the increase in international oil prices had a statistically significant positive effect on prefecture revenues (seven Bolivians of per capita revenue on average for every dollar increase in the price of oil). This implies that prefectural revenues can not only decrease once there is a drop in international oil prices, but also fluctuate at the rhythm of the volatility of that price. Also it should be noted that the increase in revenues in the hydrocarbon sector over the period studied was due not only to the increase in their prices, but also to the constant increase in the volume produced and exported. These volumes cannot increase indefinitely as there are limitations of supply and demand.

All of the issues discussed above under the scope of the fiscal institutions of municipal and prefectural decentralization, are in effect considered institutional obstacles that affect 
local economic development in Bolivia. If these are kept without any changes over time, the consequence would be ever greater disincentive to own revenue generation and dependence on transfers from central government, resulting in a major rent-seeking culture rather than the culture of local contribution (tax and non-tax).

The increased reliance of sub-national levels on transfers from central government, also threatens the central government itself, especially once those surpluses disappear, who would frequently find itself in rescue or bail out missions in particular of those subnational governments too big to let them fall into bankruptcy (soft budget problem + too big to fail). Subnational governments could also fall into liquidity and/or solvency problems due to internal management problems or in other cases by problems beyond their control, such as adverse external shocks (in particular volatility and drops in the international price of oil). But probably the worst of consequences of doing nothing would be the growing misalignment of subnational governments with their own local interests. The latter because it is local interests that encourage the participation of local jurisdiction citizens determined to find solutions to local problems and implement them through their governments in coordination with other levels. It is local participation that allows the buildup of an institutional framework of decentralization from the bottom up and not the other way around.

An already suggested solution to this problem is to link transfers to local contribution targets (tax and non-tax) at the subnational level. This would help solve the flypaper effect, reduce the seed of the soft budget problem, reduce the risks associated with oil price volatility and also improve incentives to own revenue generation, but would not solve the misalignment problem. Moreover, this proposal implies a policy change that may be difficult to achieve, besides being identified as unfair since only the largest and more developed subnationals would have a real chance to increase own revenues. Thus a mixed system could be established between free transfers and transfers subject to local contribution goals, which could vary according to some classification of subnationals. However, any solution linking transfers to own revenue generation, must first solve the problem of the need to generate revenues in addition to transfers received or the existence of subnational fiscal surpluses. The not committed subnational surpluses should be accumulated in a fund on a separate reserve account for a rainy day, which could be administered by a specialized investor.

The misalignment problem is more related to the local definition of the objectives of decentralization, which should be aligned to "strictly local interests". While the MDGs could be quantitative goals of decentralization for the central government, more qualitative goals 
in health, education and housing could be part of local interests. Similarly, employment and income generation goals could be economic goals of greatest local interest. On the one hand, transfers could be linked to achievements expressed in MDG goals, but could also be linked to achievements expressed in goals established by strictly local interests. Undoubtedly, the second road is more demanding in terms of local participation, plus it requires a behavior change in central government. Here it is possible that the central government could anyway insist on national social goals; new quantitative minimums, this time accompanied by qualitative minimums. However, subnational governments could add to these other more local goals in basic infrastructure (water, energy, transportation and communications associated with home improvement projects) and even support economic growth goals (development of organizations dedicated to production, industry, commerce and entertainment) in order to exploit all possible sources of local employment generation.

While linking transfers to outcomes helps to solve the problem of ex post costs, it has no relationship with ex ante costs where other distortionary incentive problems arise. This means that the solution of the problem of passing the ex-ante and ex post costs simultaneously to subnationals involves substantial local participation in defining the objectives and goals of interest to the jurisdiction, plus the local leadership commitment to greater own revenue collection and effective local effort in meeting fiscal collection goals. In short, a more interconnected and coordinated local involvement that goes beyond the purely political, since it requires design of more technical processes, coordinated and above all real local effort.

The question now is what should be the design of the institutions of decentralization such that it accomplishes the highest degree of achievement of the objectives of local development, taking advantage of the involvement, enthusiasm and local effort that would allow a combination of own and not-own revenues (probably with dominance of not-own) so as to minimize the risk of self-destructive behavior (misalignment, flypaper, soft budget and the disincentive to own revenue generation). Perhaps the answer is already contained in the approach of autonomies as a vision of local development, because it captures the need that decentralization responds to bottom up processes and not the other way around. In this direction, the local contribution not only achieves economic objectives (locals contribute to spending and investment in the goods and services they need, according to their valuations and budget constraints) and administrative objectives (contributes to the culture of local contribution and improves the culture of surveillance and accountability), but also political objectives, because the greater is the local contribution the greater is the voice and influence 
in decisions over the use of resources and therefore greater autonomy and evolutionary goals, because the institutions of decentralization must genuinely seek to free the local economic potential, which corresponds to a more productive decentralization rather than purely distributive, requiring greater local control of decisions about the allocation of resources. Because of its importance, the correction of incentives in the institutional design requires political will and leadership from all players. The local contribution requires that locals are convinced that it is the way for increasing control of their own development and also requires that the central government wants to transfer that greater control to locals, through the management of incentives connected to transfers.

Artículo recibido: 10 de diciembre de 2012 Aceptado: 25 de marzo de 2013 


\section{References}

1. Ajwad, M. I. \& Wodon, Q. (2007). Do local Governments Maximize Access Rates to Public Services across Areas? A Test Based on Marginal Benefit Incidence Analysis. The Quarterly Review of Economics and Finance, 47 (2) 242-260.

2. Aragon, Fernando M. (2008). "The Flypaper Effect Revisited". The Suntory Centre, London School of Economics and Political Science, EOPP/2009/4.

3. Banco Mundial (2006). "Hacia una descentralización incluyente”. Tomo II: Análisis Técnico Detallado, Análisis de la Situación Institucional y de Gobernabilidad (IGR). La Paz: Banco Mundial.

4. Barja, Gover, Villarroel, Sergio and Zavaleta, David (2012). Diseño institucional e incentivos implícitos en la descentralización boliviana. La Paz: Fundación PIEB Editores, PIEB-MpD/UCB.

5. Barrios Suvelza, Franz Xavier (2002). El Estado triterritorial: una nueva descentralización para Bolivia. La Paz: Plural Editores, FES-ILDIS.

6. Bird, R. M. (1993). Threading the Fiscal Labyrinth: Some Issues in Fiscal Decentralization. National Tax Journal, 46 (2) 207-227.

7. Bird, R. M. and Vaillancourt, F. (Eds.) (1998). Fiscal Decentralization in Developing Countries. New York and London: Cambridge University Press.

8. Bourguignon, François (2002). "The Growth Elasticity of Poverty Reduction: Explaining Heterogeneity across countries and Time Periods". Working Paper No 200203. DELTA and The World Bank.

9. ------- (2004) “The Poverty-Growth-Inequality Triangle”. The World Bank. Paper.

10. Canavire-Bacarreza, G.; Martínez-Vázquez, J. and Sepúlveda, C. (2011). "Subnational Revenue Mobilization in Peru”. IADB Research Network Project. Forthcoming.

11. DeFiguereido, Rui and Weingast, Barry (1997). Self-enforcing federalism. Journal of Law, Economics and Organization, 21, 103-135.

12. Escalante, S. (1997). La Participación Popular y sus efectos sobre la equidad: un análisis a partir de la evolución de los planes anuales operativos municipales. In G. Gray-Molina (Ed.) Participación Popular: construyendo políticas públicas locales en Bolivia. La Paz: Unidad de Análisis de Políticas Sociales (UDAPSO). 
13. Espada, J.L. (2011). Financiamiento y gasto de las gobernaciones: autonomía sin reforma. Centro de Estudios para el Desarrollo Laboral y Agrario (CEDLA). Serie Transparencia Fiscal, La Paz, Marzo.

14. Faguet, J. P. (2004). "Does decentralization increase government responsiveness to local needs? Evidence from Bolivia”. Journal of Public Economics, Vol. 88 No. 4, pp. 867-893.

15. Finot, Iván (2003). El proceso boliviano de descentralización: análisis comparativo y pautas para seguir adelante. En La descentralización que se viene: propuestas para la (re)constitución del nivel estatal intermedio (pp. 131-167). La Paz: Plural EditoresFES/ILDIS,

16. -------- (2005). Descentralización, transferencias territoriales y desarrollo local. Revista de la CEPAL, 86, 29-46.

17. Gamkhar, Shama and Shah, Anwar (2007). The Impact of Intergovernmental Fiscal Transfers: A Synthesis of the Conceptual and Empirical Literature. In Robin Boadway and Anwar Shah (Eds.) Intergovernmental Fiscal Transfers: Principles and Practice (pp. 225-258), Public Sector Governance and Accountability Series, Washington: World Bank

18. Graham, C. (1997). "Apoyo para las reformas de mercado en Bolivia: los programas de capitalización y participación popular". In M. H. Peirce (Ed.), Capitalización: el modelo boliviano de reforma social y económica. (pp. 23-70). Washington: The Woodrow Wilson Center, North South Center.

19. Gray-Molina, G. (2004). "Popular Participation and Poverty Reduction in Bolivia". In I. Licha (Ed.) Citizens in Charge Managing Local Budgets in East Asia and Latin America. (pp. 223-245) Washington: Banco Interamericano de Desarrollo.

20. Gray-Molina, G., Pérez de Rada, E. and Yáñez, E. (1999). "La economía política de reformas institucionales en Bolivia”. Documento de Trabajo R-350. Washington: Banco Interamericano de Desarrollo.

21. Grootaert, C. and Narayan, D. (2004). Local Institutions, Poverty and Household Welfare in Bolivia. World Development, 32 (7), 1179-1198.

22. Hines, James R. and Thaler, Richard H. (1995). Anomalies: The Flypaper Effect. The Journal of Economic Perspectives, 9 (4), 217-226. 
23. Inchauste, G. (2009). Decentralization in Bolivia: has it made a difference?. In E. Ahmad, y G. Brosio (Eds.), Does Decentralization Enhance Service Delivery and Poverty Reduction? (pp. 161-191). Cheltenham, UK: Edward Elgar Publishing.

24. Jin, Hehui; Qian, Yingyi and Weingast, Barry (2005). Regional Decentralization and Fiscal Incentives: Federalism, Chinese Style. Journal of Public Economics, 89, 1719-1742.

25. Kornai, Janos (1986). The Soft Budget Constraint. Kyklos, 39 (1), 3-30.

26. Kornai, Janos; Maskin, Eric and Roland, Gérard (2003). "Understanding the Soft Budget Constraint”, Journal of Economic Literature 41, 1095-1136.

27. Luján, M. (2004). "Gobernabilidad municipal: análisis de la aplicación del voto constructivo de censura”. In: Municipalización: diagnóstico de una década, (Tomo II, pp. 145-185). La Paz: Plural Editores - FES/ILDIS.

28. Martínez-Vázquez, Jorge and Timofeev, Andrey (2009). "Decentralization Measures Revisited”. Working Paper 09-13, Andrew Young School of Policy Studies, Georgia State University.

29. Ministerio de Autonomías (2011). Estado de situación sociodemográfica de los municipios de Bolivia (2005-2009). Observatorio Bolivia Democrática. La Paz: Editorial Presencia.

30. Musgrave, Richard (1959). "The Theory of Public Finance: A Study in Public Economy”. New York: McGraw-Hill.

31. North, Douglass (1990).Institutions, institutional change and economic performance. New York: Cambridge University Press.

32. Oates, Wallace E. (1972). Fiscal Federalism. New York: Harcourt Brace Jovanovich.

33. ----- (2005). Toward a second generation theory of fiscal federalism. International Tax and Public Finance, 12, 349-373.

34. O’Donnell, G. (1993). On the State, Democratization and Some Conceptual Problems: A Latin American View with Glances at Some Postcommunist Countries. World Development, 21 (8), 1355-1369.

35. O'Neill, K. M. (2003). Decentralization as an Electoral Strategy. Comparative Political Studies, 36 (9), 1068-1091.

36. - (2005). "Decentralizing the State: Elections, Parties, and Local Power in the Andes”. Cambridge: Cambridge University Press. 
37. Programa de las Naciones Unidas para el Desarrollo, PNUD (2007). "El estado del Estado en Bolivia". Informe Nacional sobre Desarrollo Humano, La Paz.

38. Prud'homme, Remy (1995). “On the Dangers of Decentralization”, World Bank Economic Review, 10 (2), 201-220.

39. Qian, Yingyi and Weingast, Barry (1997). Federalism as a commitment to preserving market incentives. Journal of Economic Perspectives, 11 (4), 83-92.

40. Reid, G. J. and Malik, W. H. (1994). Overview. In Chaudhry, S. A., Reid, G. J. y Malik, W.H. (Eds.), Civil Service Reform in Latin America and the Caribbean. Washington D.C., World Bank Technical Paper Number 259.

41. Roca, J. L. (2005). Fisonomía del regionalismo boliviano. La otra cara de la historia. Santa Cruz: Editorial El País, tercera Edición.

42. ------ (2007). "Estatalidad: Entre la Pugna Regional y el Institucionalismo", Cuadernos de Futuro 21, Regiones y Poder Constituyente en Bolivia. Una Historia de Pactos y Disputas,

43. Rodríguez Ostria, G. (1995). "Estado y municipio en Bolivia: la Ley de Participación Popular en una perspectiva histórica”. La Paz: Ministerio de Desarrollo Sostenible y Medio Ambiente, Secretaría Nacional de Participación Popular.

44. Rojas Ortuste, G. (1997). “El diseño del Estado (y sociedad) pluralista. La construcción boliviana de la democracia”. In El pulso de la democracia: participación ciudadana $y$ descentralización en Bolivia (pp. 211-238). Ministerio de Desarrollo Humano, Secretaría Nacional de Participación Popular. Caracas: Editorial Nueva Sociedad.

45. Villarroel-Böhrt, Sergio (2005). "Balanzas fiscales departamentales y costeo en la administración pública”. Estudio No 1 de la serie: Documentos de Trabajo hacia la Constituyente. La Paz: Plural Editores.

46. Weingast, Barry (1995). The economic role of political institutions: Market-preserving federalism and economic development. The Journal of Law, Economics and Organization, 11, 1-31.

47. ------ (2009). Second Generation fiscal federalism: The implications of fiscal incentives. Journal of Urban Economics, 65, 279-293.

48. Wiesner, Eduardo (2003). Fiscal Federalism in Latin America: From Entitlements to Markets. Washington: Inter-American Development Bank.

49. Wildasin, David (2004). The Institutions of Federalism: Toward an Analytical Framework. National Tax Journal, LVII (2), 247-272, Part 1. 
Appendix 1

Detail of transfers to municipalities

\begin{tabular}{|c|c|c|c|}
\hline Transfer & Source of funds & Distribution criteria & $\begin{array}{l}\text { Sector conditionality and } \\
\text { by type of expenditure }\end{array}$ \\
\hline $\begin{array}{l}\text { Revenue sharing } \\
\text { (Coparticipacion } \\
\text { tributaria) }\end{array}$ & $\begin{array}{l}20 \% \text { of current } \\
\text { income from IVA, } \\
\text { IT, RC-IVA, IUE, ICE, } \\
\text { GA, ISAE, ITGB }\end{array}$ & $\begin{array}{l}\text { Municipal population } \\
\text { according to } \\
\text { the census. }\end{array}$ & $\begin{array}{l}\text { - } 85 \% \text { for investment and } 15 \% \\
\text { for current expenditures. } \\
\text { - } 7 \% \text { of the } 20 \% \text { for the } \\
\text { SUMI program. } \\
\text { - } 40 \% \text { of the annual } \\
\text { SMGV bonus. }\end{array}$ \\
\hline $\begin{array}{l}\text { Social and } \\
\text { Productive } \\
\text { Investment } \\
\text { Fund (FPS) }\end{array}$ & $\begin{array}{l}\text { - Official } \\
\text { International } \\
\text { Cooperation to } \\
\text { the Government } \\
\text { of Bolivia. } \\
\text { - Credit from } \\
\text { Multilateral } \\
\text { Organizations. }\end{array}$ & $\begin{array}{l}\text { - } 70 \% \text { to municipalities } \\
\text { according to } \\
\text { poverty levels. } \\
\text { - } 30 \% \text { in equal } \\
\text { shares to the } \\
\text { nine prefectures, } \\
\text { distributed to } \\
\text { municipalities based } \\
\text { on poverty levels. }\end{array}$ & $\begin{array}{l}\text { Defined by the international } \\
\text { donor. Priority areas in } \\
\text { the Poverty Reduction } \\
\text { Strategy: education, health, } \\
\text { sanitation, rural energy, } \\
\text { rural development, natural } \\
\text { resources and environment. }\end{array}$ \\
\hline $\begin{array}{l}\text { Debt relief } \\
\text { initiative for Highly } \\
\text { Indebted Poor } \\
\text { Countries (HIPC II) }\end{array}$ & $\begin{array}{l}\text { Debt Relief } \\
\text { Program }\end{array}$ & Poverty levels & $\begin{array}{l}\text { Resources are } \\
\text { channeled through: } \\
\text { - The Municipal Solidarity } \\
\text { Fund for School Education } \\
\text { and Public Health (U.S. \$ } \\
27 \text { million per year, } 70 \% \text { for } \\
\text { primary and secondary } \\
\text { education and 30\% for } \\
\text { health) and the SUMl } \\
\text { National Solidarity Fund. } \\
\text { - The } 2002 \text { National } \\
\text { Dialogue Special Account } \\
\text { receives the difference } \\
\text { (10\% for health, 20\% for } \\
\text { school maintenance } \\
\text { and equipment and } \\
\text { 70\% for infrastructure). }\end{array}$ \\
\hline $\begin{array}{l}\text { Direct } \\
\text { Hydrocarbons } \\
\text { Tax (IDH) }\end{array}$ & $\begin{array}{l}\text { From the } 32 \% \text { tax } \\
\text { on the value of } \\
\text { hydrocarbons } \\
\text { production, } \\
58 \% \text { goes to } \\
\text { departments } \\
\text { divided between } \\
\text { prefectures, } \\
\text { municipalities } \\
\text { and universities. }\end{array}$ & $\begin{array}{l}\text { According to Decree } \\
29322 \text { of } 24 / 10 / 2007, \\
\text { municipalities receive } \\
66.99 \% \text { of IDH, which } \\
\text { is distributed to } \\
\text { beneficiaries according } \\
\text { to the number of } \\
\text { inhabitants of the } \\
\text { municipal jurisdiction. }{ }^{*}\end{array}$ & $\begin{array}{l}\text { Municipalities: education, } \\
\text { health, local economic } \\
\text { development, promotion } \\
\text { of employment and } \\
\text { collective security. }\end{array}$ \\
\hline
\end{tabular}

Source: Adapted from World Bank (2006).

${ }^{*}$ ) In practice municipalities receive approximately $40 \%$ before the distribution of the Renta Dignidad and between $31 \%$ and $35 \%$ after contributing to such rent (according to approximations made by the Fundación Jubileo (2009) and Medinaceli (2007).

ICE: Specific consumption tax; GA: customs tariff; ISAE: Abroad departures tax; ITGB: Free asset transfer tax; SUMI: Mother-child universal insurance; SMGV: Free old-age medical insurance. 
Appendix 2

Detail of transfers to prefectures

\begin{tabular}{|c|c|c|c|}
\hline Transfer & Source of funds & $\begin{array}{l}\text { Distribution } \\
\text { Criteria }\end{array}$ & $\begin{array}{l}\text { Conditionality sector and } \\
\text { by type of expenditure }\end{array}$ \\
\hline $\begin{array}{l}\text { Revenue sharing } \\
\text { of the Special Tax } \\
\text { on Hydrocarbons } \\
\text { and Derivatives } \\
\text { (IEHD) }\end{array}$ & $25 \%$ of IEHD & $\begin{array}{l}\text { - } 50 \% \text { on the basis } \\
\text { of population. } \\
\text { - } 50 \% \text { equally } \\
\text { among } \\
\text { departments. }\end{array}$ & $\begin{array}{l}\text { Road infrastructure of the } \\
\text { National Road Service } \\
\text { (SNC) (as counterpart } \\
\text { to SNC projects). }\end{array}$ \\
\hline $\begin{array}{l}\text { Departmental } \\
\text { Compensation } \\
\text { Fund (FCD) }\end{array}$ & $\begin{array}{l}10 \% \text { of IEHD that } \\
\text { corresponds } \\
\text { to the national } \\
\text { level budget. }\end{array}$ & $\begin{array}{l}\text { The amount } \\
\text { required by } \\
\text { departments to } \\
\text { reach the national } \\
\text { average per } \\
\text { capita royalty }\end{array}$ & Open \\
\hline $\begin{array}{l}\text { Hydrocarbons } \\
\text { Royalties }\end{array}$ & $\begin{array}{l}\text { - } 11 \% \text { of the } \\
\text { Department } \\
\text { hydrocarbons } \\
\text { production value. } \\
\text { - } 1 \% \text { of the national } \\
\text { hydrocarbons } \\
\text { production value } \\
\text { goes to royalty } \\
\text { compensation } \\
\text { for the Beni }(2 / 3) \\
\text { and Pando }(1 / 3) \\
\text { Departments. }\end{array}$ & $\begin{array}{l}\text { Received only by } \\
\text { those departments } \\
\text { where } \\
\text { hydrocarbon } \\
\text { production } \\
\text { occurs and, in the } \\
\text { case of royalty } \\
\text { compensation } \\
\text { also Beni and } \\
\text { Pando }\end{array}$ & Open \\
\hline $\begin{array}{l}\text { Direct } \\
\text { Hydrocarbons Tax } \\
\text { (IDH) }\end{array}$ & $\begin{array}{l}\text { From the } 32 \% \text { tax on } \\
\text { the hydrocarbons } \\
\text { production } \\
\text { value, } 58 \% \text { goes } \\
\text { to departments } \\
\text { divided between } \\
\text { prefectures, } \\
\text { municipalities } \\
\text { and universities. }\end{array}$ & $\begin{array}{l}\text { According } \\
\text { Decree } 29322 \\
\text { of } 24 / 10 / 2007 \\
\text { prefectures receive } \\
24.4 \% \text { of IDH* }\end{array}$ & $\begin{array}{l}\text { Departments: social } \\
\text { economic development, } \\
\text { collective security. }\end{array}$ \\
\hline
\end{tabular}

$\left.{ }^{*}\right)$ In practice prefectures receive about $16 \%$ before the distribution of the Renta Dignidad and about $10 \%$ after contributing to such rent (according to approximations made by the Fundación Jubileo (2009) and Medinaceli (2007). 


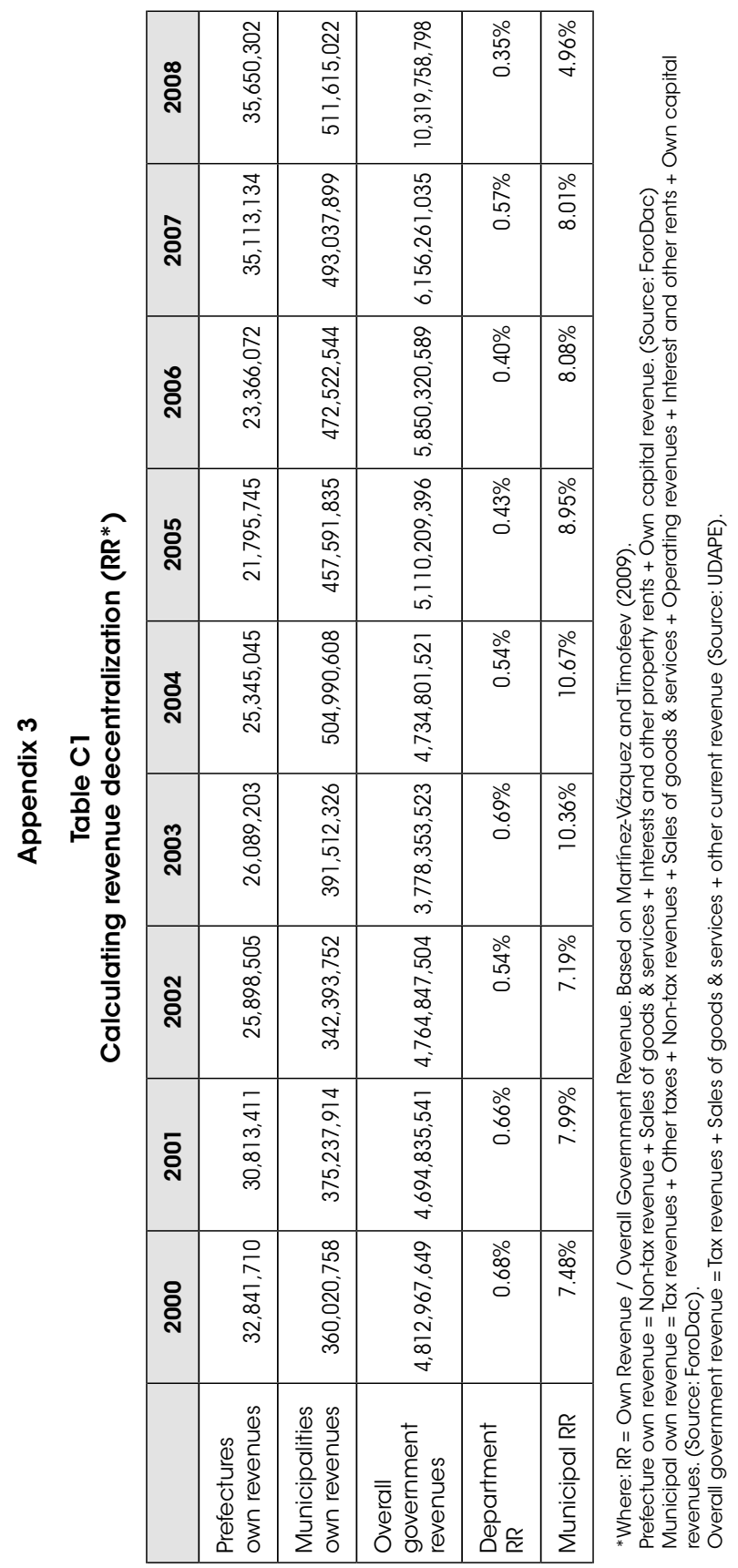




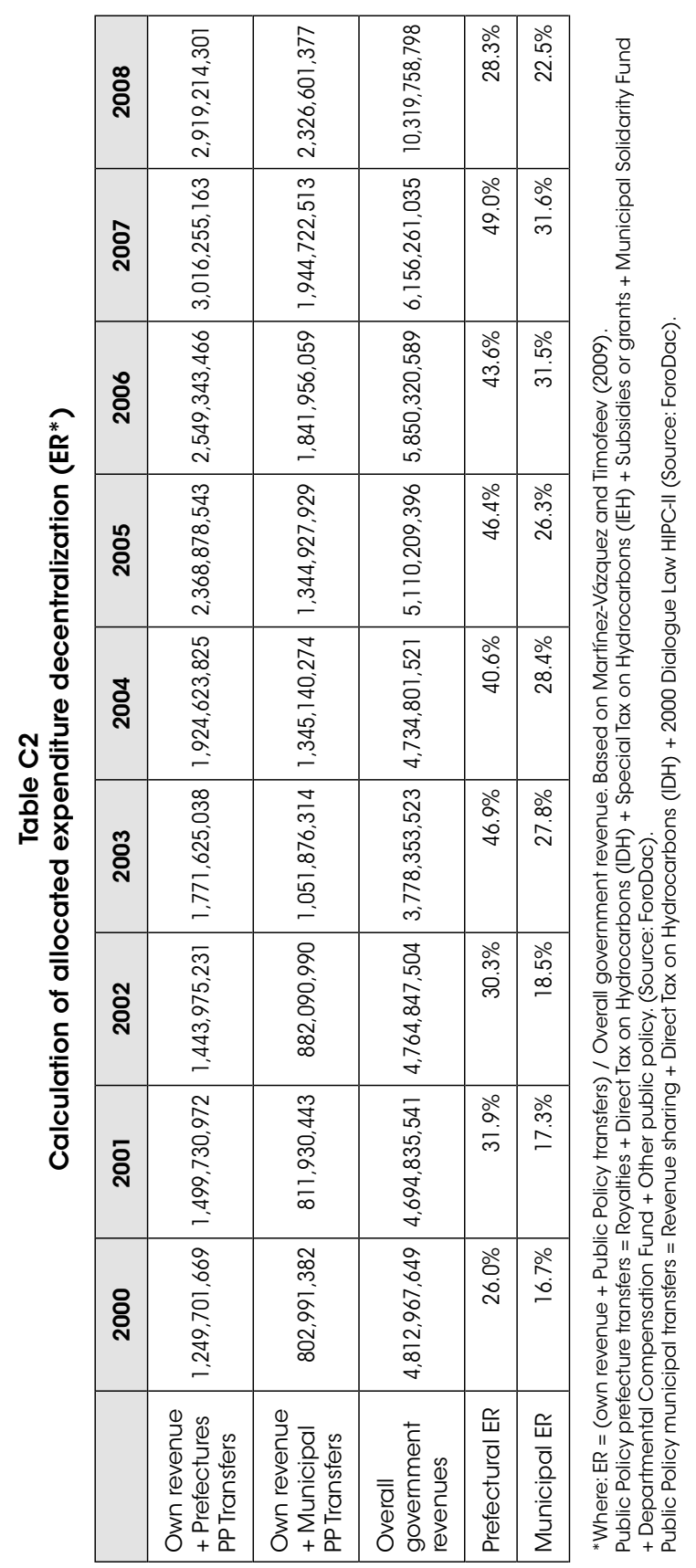


Table C3

Calculation of the composite decentralization coefficient $(C R=R R /(1-E R))$

\begin{tabular}{|l|r|r|r|r|r|r|r|r|r|}
\hline & $\mathbf{2 0 0 0}$ & $\mathbf{2 0 0 1}$ & $\mathbf{2 0 0 2}$ & $\mathbf{2 0 0 3}$ & $\mathbf{2 0 0 4}$ & $\mathbf{2 0 0 5}$ & $\mathbf{2 0 0 6}$ & $\mathbf{2 0 0 7}$ & $\mathbf{2 0 0 8}$ \\
\hline Prefectural CR & $0.9 \%$ & $1.0 \%$ & $0.8 \%$ & $1.3 \%$ & $0.9 \%$ & $0.8 \%$ & $0.7 \%$ & $1.1 \%$ & $0.5 \%$ \\
\hline Municipal CR (left axis) & $9.0 \%$ & $9.7 \%$ & $8.8 \%$ & $14.4 \%$ & $14.9 \%$ & $12.2 \%$ & $11.8 \%$ & $11.7 \%$ & $6.4 \%$ \\
\hline
\end{tabular}

Source: Own elaboration based on Martínez-Vázquez and Timofeev (2009)

Figure C1: Revenue Decentralization (RR)

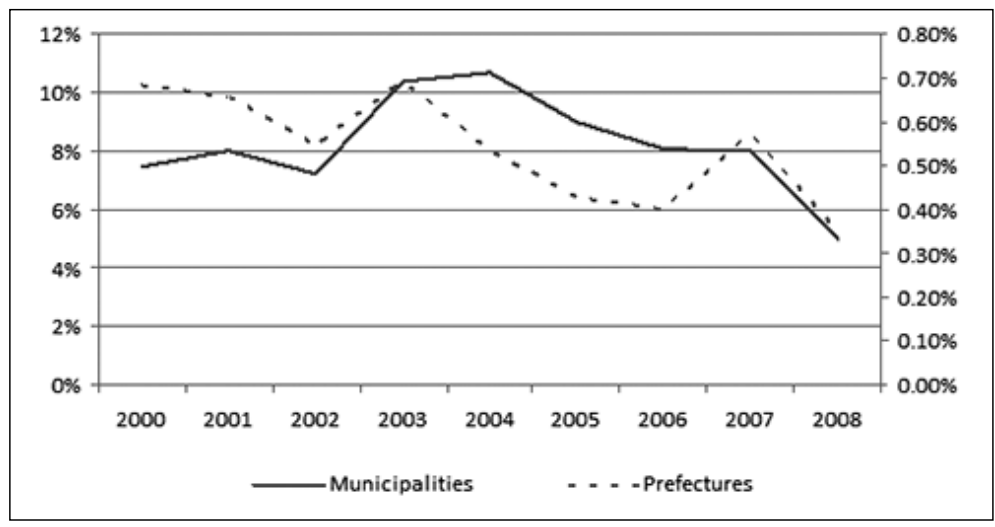

Source: Own elaboration

Figure C2: Expenditure Decentralization (ER)

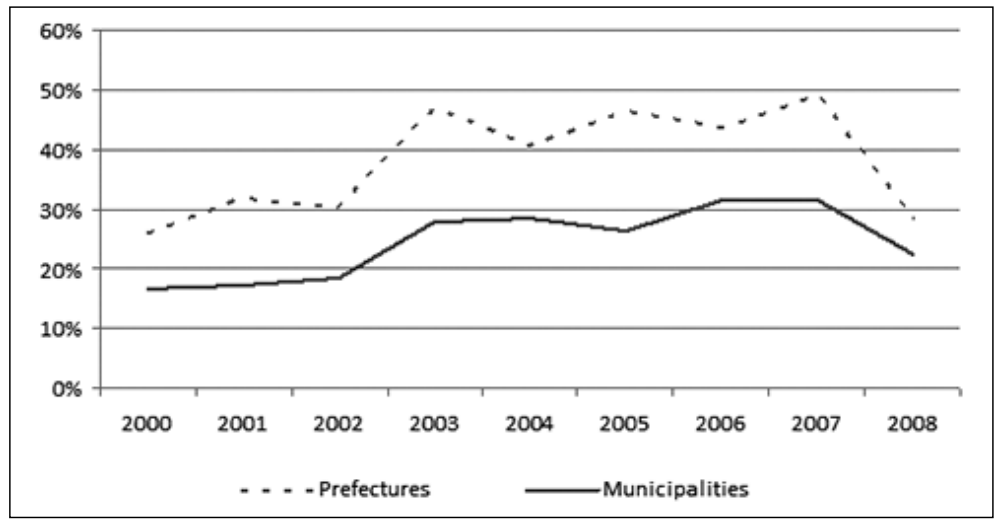

Source: Own elaboration 
Figure C3: Composite coefficient ( $C R=R R /(1-E R)$ )

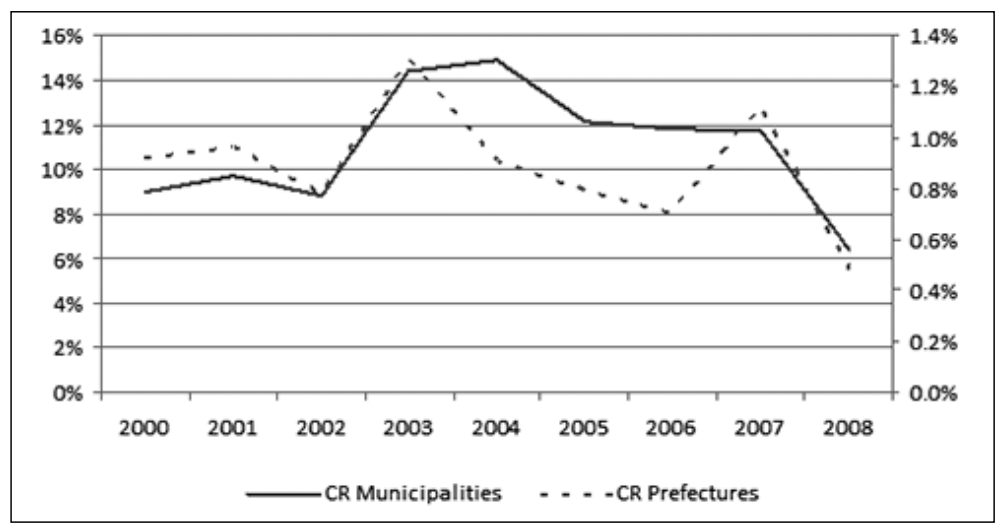

Source: Own elaboration 


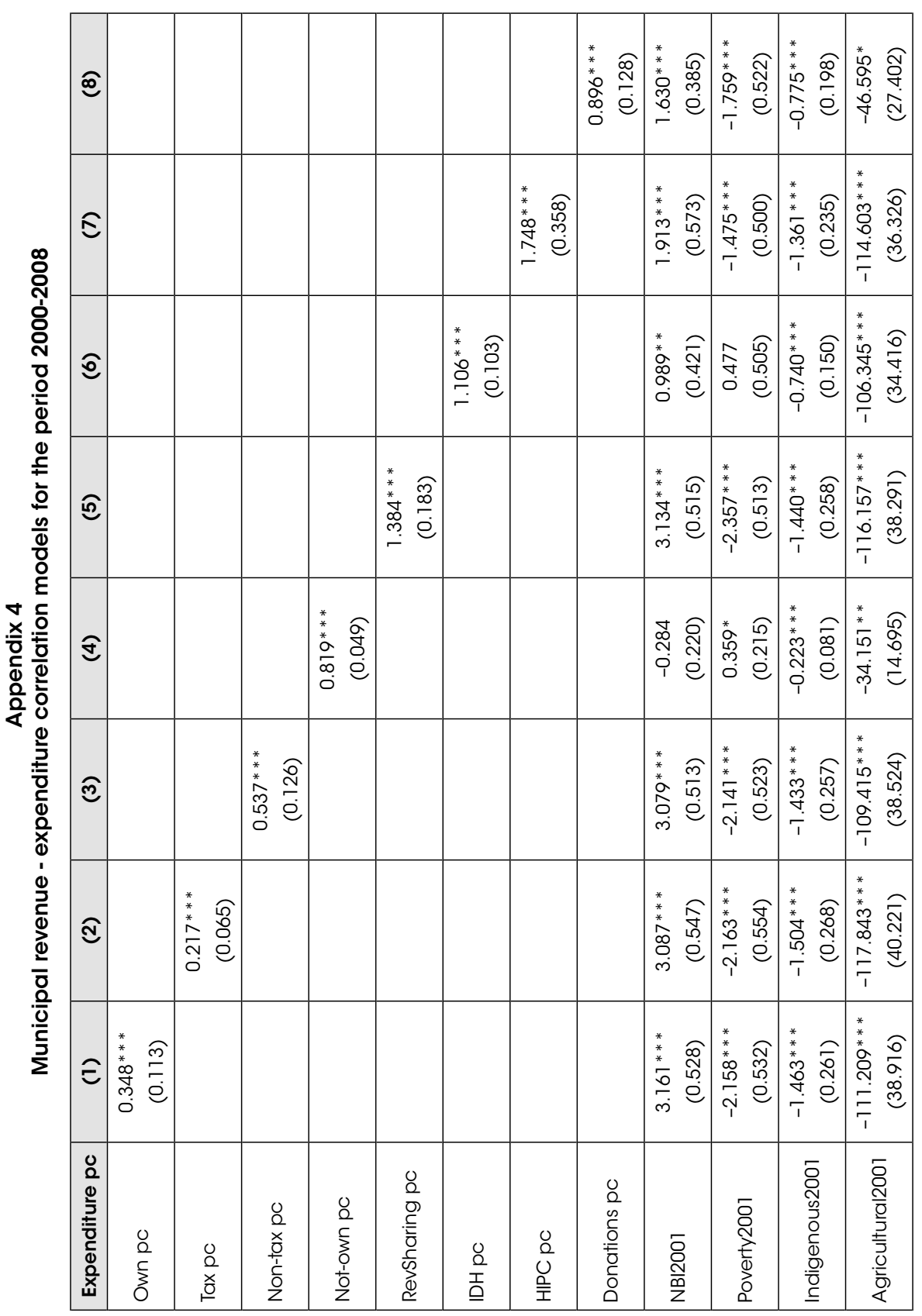




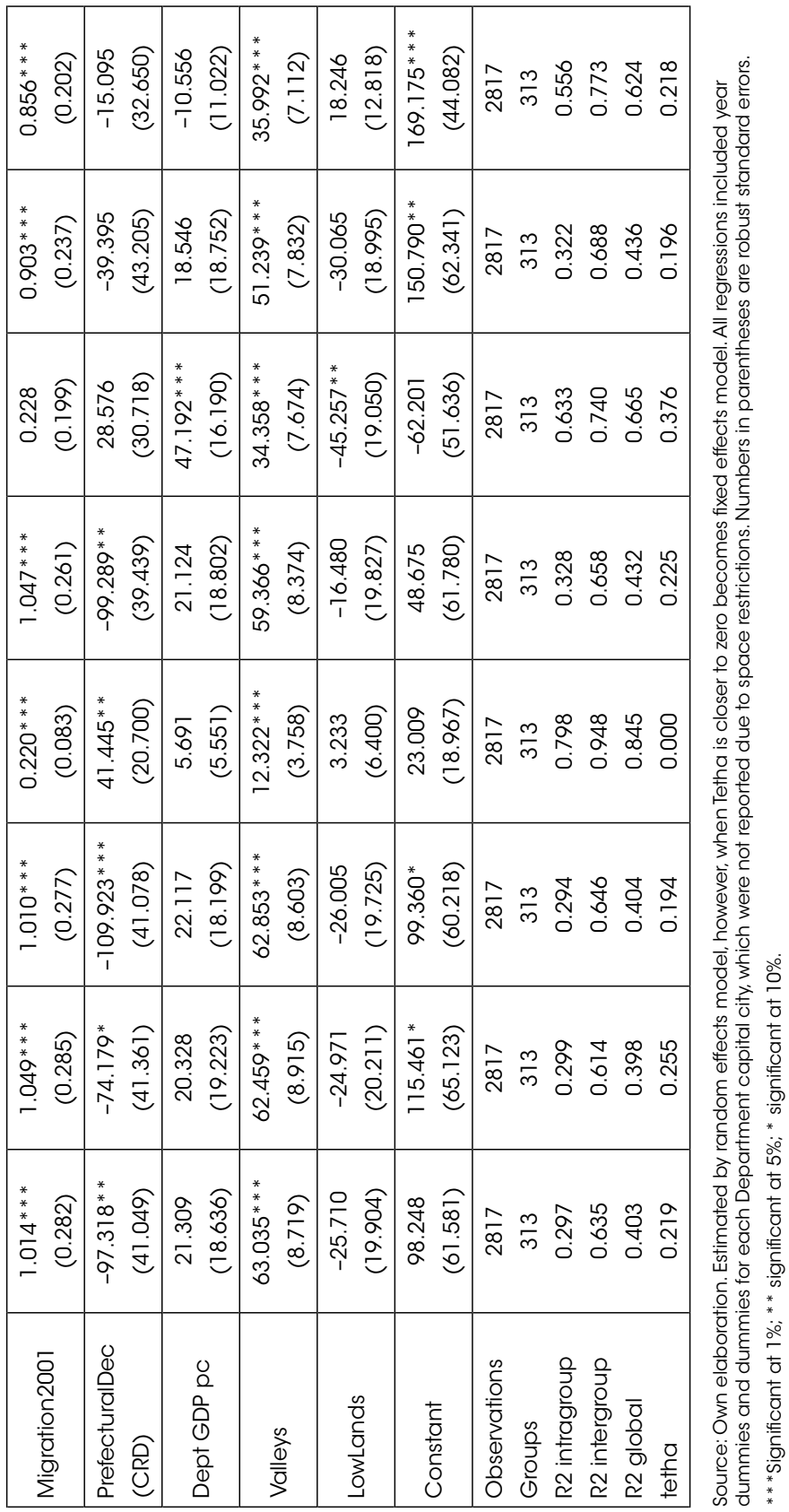




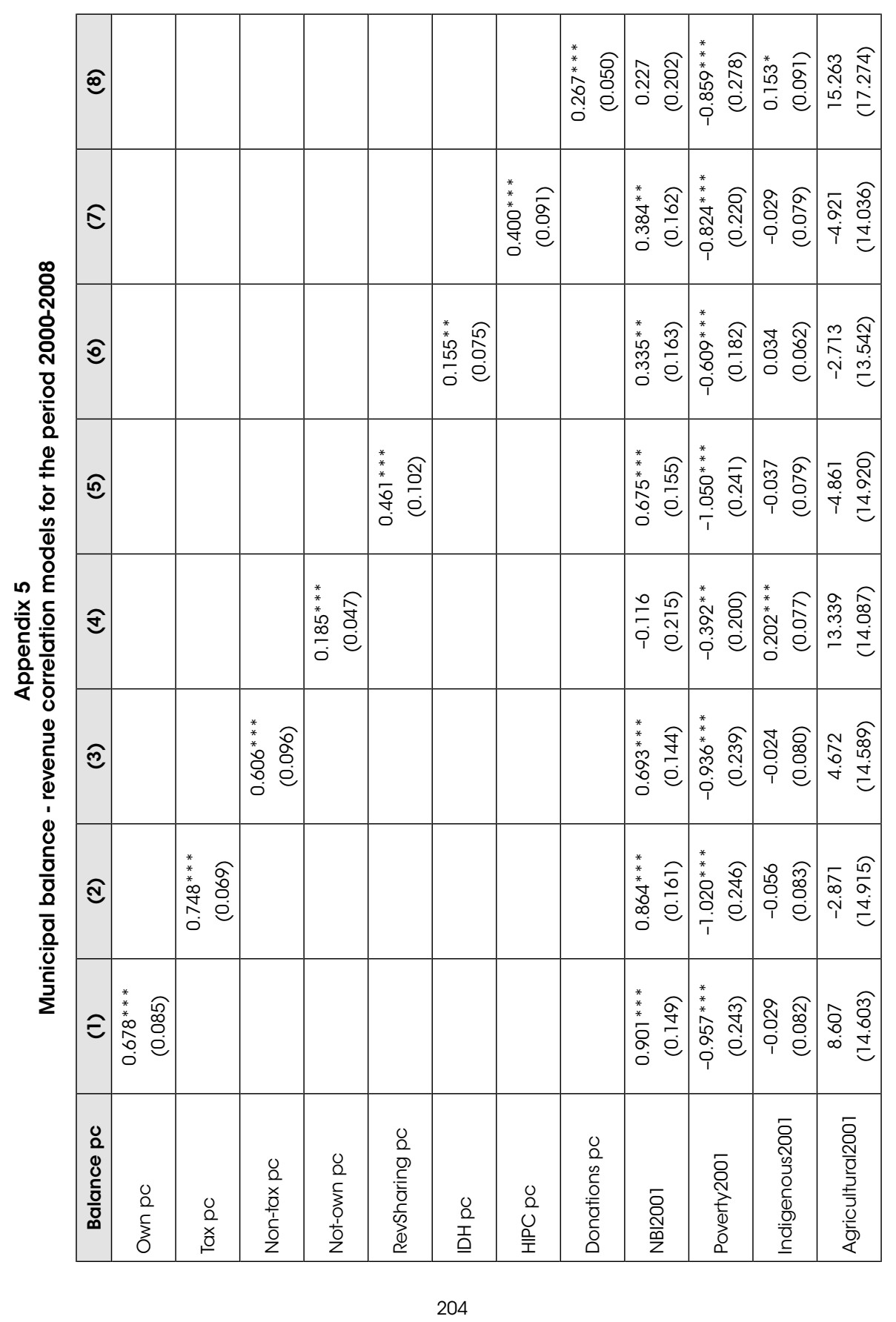




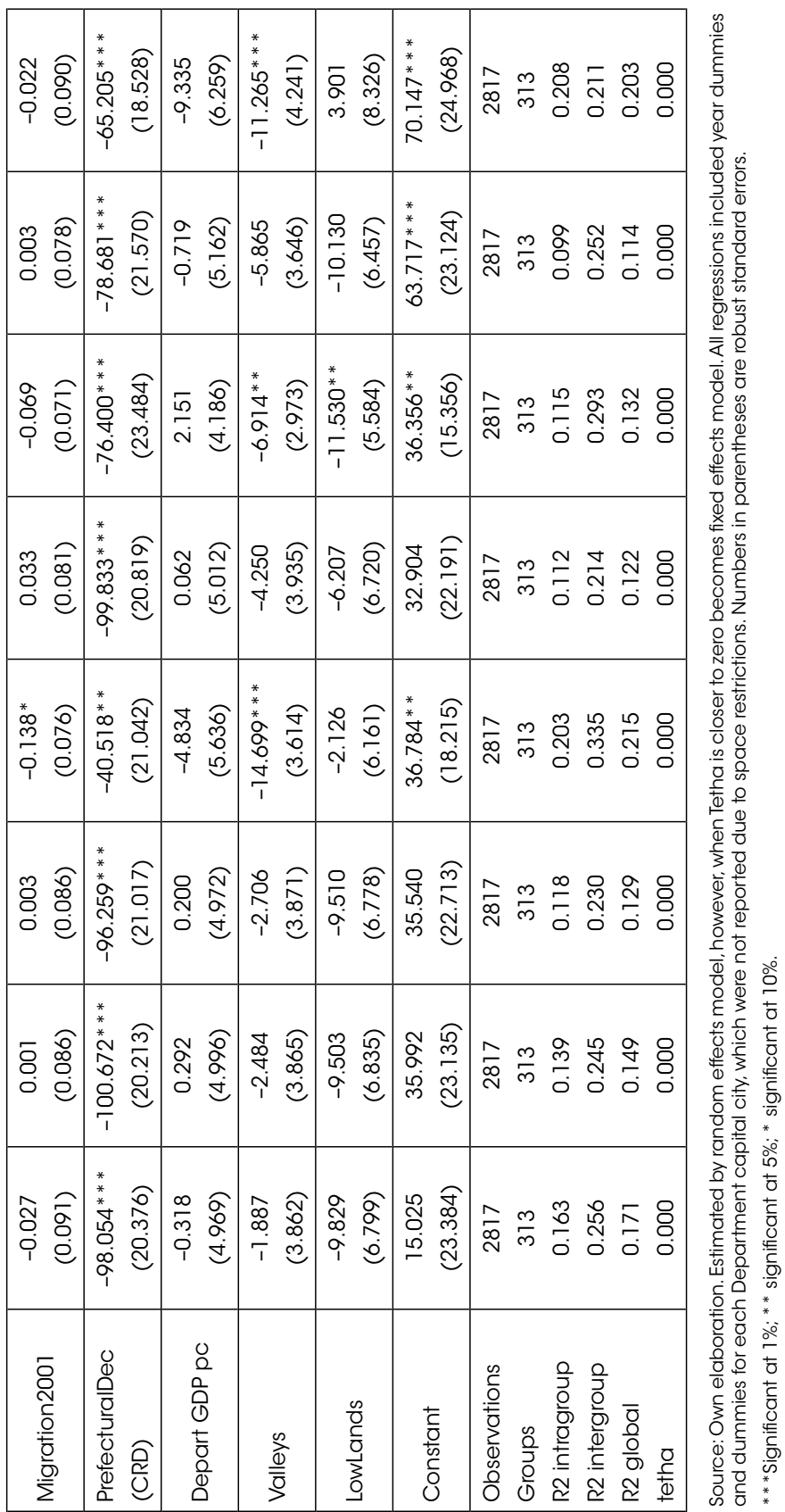




\begin{tabular}{|c|c|c|c|c|c|c|c|c|c|c|c|}
\hline क & & & & $\begin{array}{ll}= & 0 \\
\equiv & 0 \\
i & 0\end{array}$ & 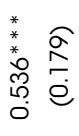 & & 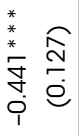 & $\begin{array}{ll}\circ & \infty \\
\infty & \vdots \\
\circ & \overline{0} \\
0 & 0\end{array}$ & 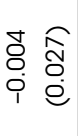 & 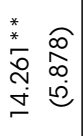 & $\begin{array}{ll}\circ & \text { ๖ } \\
\circ & \circ \\
\circ & \circ \\
\circ & \stackrel{C}{ }\end{array}$ \\
\hline 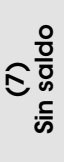 & & & 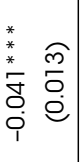 & & 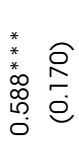 & & 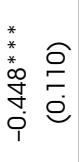 & 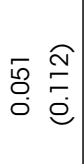 & $\begin{array}{ll}\overparen{N} & \widehat{D} \\
0 & 0 \\
0 & 0 \\
1 & 0\end{array}$ & 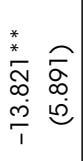 & 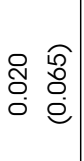 \\
\hline 응 & & 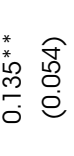 & & & 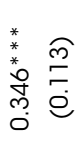 & & 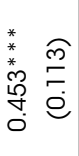 & $\begin{array}{ll}\bar{\delta} & \approx \\
0 & \bar{E} \\
0 & 0\end{array}$ & $\begin{array}{ll} & 0 \\
8 & 0 \\
0 & 0 \\
0 & 0\end{array}$ & 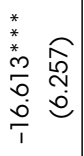 & 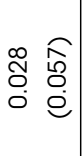 \\
\hline હ & 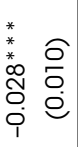 & & & & 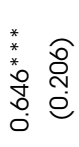 & & 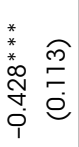 & 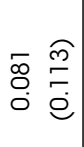 & $\begin{array}{ll}\mathscr{N} & \widehat{m} \\
0 & 0 \\
0 & 0 \\
1 & 0\end{array}$ & 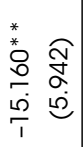 & 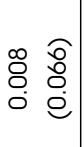 \\
\hline ๑ & & & & 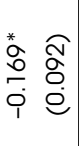 & 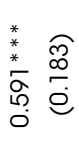 & 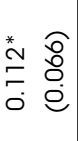 & 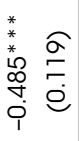 & 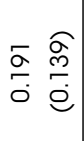 & 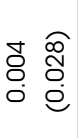 & 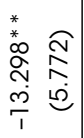 & $\begin{array}{ll} & \widehat{0} \\
8 & 0 \\
0 & 0 \\
1 & 0\end{array}$ \\
\hline กำ & & & 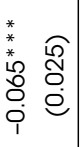 & & 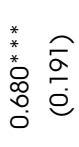 & 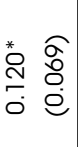 & 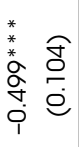 & 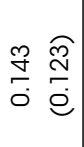 & 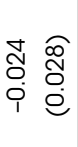 & 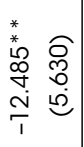 & $\begin{array}{ll}\circ & 0 \\
\circ & 0 \\
\circ & 0 \\
0 & 0\end{array}$ \\
\hline 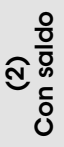 & & 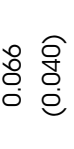 & & & 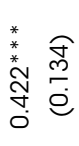 & $\begin{array}{ll}* & 0 \\
0 & 0 \\
\circ & 0 \\
\circ & 0 \\
0 & 0\end{array}$ & 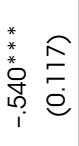 & 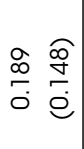 & 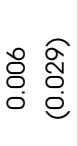 & 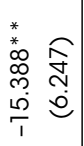 & 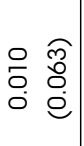 \\
\hline 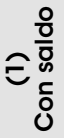 & 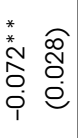 & & & & 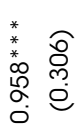 & 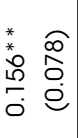 & 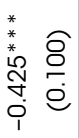 & 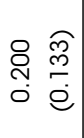 & 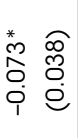 & 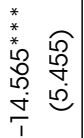 & $\begin{array}{ll}2 & 0 \\
0 & 0 \\
0 & 0 \\
0 & 0\end{array}$ \\
\hline $\begin{array}{l}0 \\
\vdots \\
\frac{2}{2} \\
\text { ó }\end{array}$ & $\begin{array}{l}0 \\
0 \\
\frac{1}{1} \\
3 \\
0 \\
\frac{1}{0} \\
2\end{array}$ & 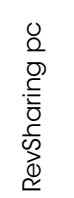 & $\begin{array}{l}0 \\
\stackrel{0}{0} \\
\text { 工⿱士口⿱ }\end{array}$ & $\begin{array}{l}0 \\
0 \\
0 \\
\vdots \\
\text { İ }\end{array}$ & 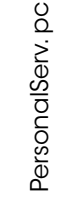 & $\begin{array}{l}0 \\
0 \\
0 \\
0 \\
\frac{1}{0} \\
\frac{0}{0} \\
0\end{array}$ & $\begin{array}{l}\overline{\text { D }} \\
\text { ⿳亠丷⿵冂丶 }\end{array}$ & $\begin{array}{l}\overline{8} \\
\stackrel{0}{1} \\
\stackrel{1}{0} \\
0 \\
0\end{array}$ & 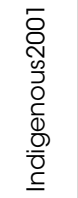 & 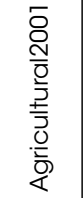 & 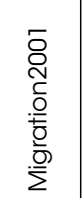 \\
\hline
\end{tabular}




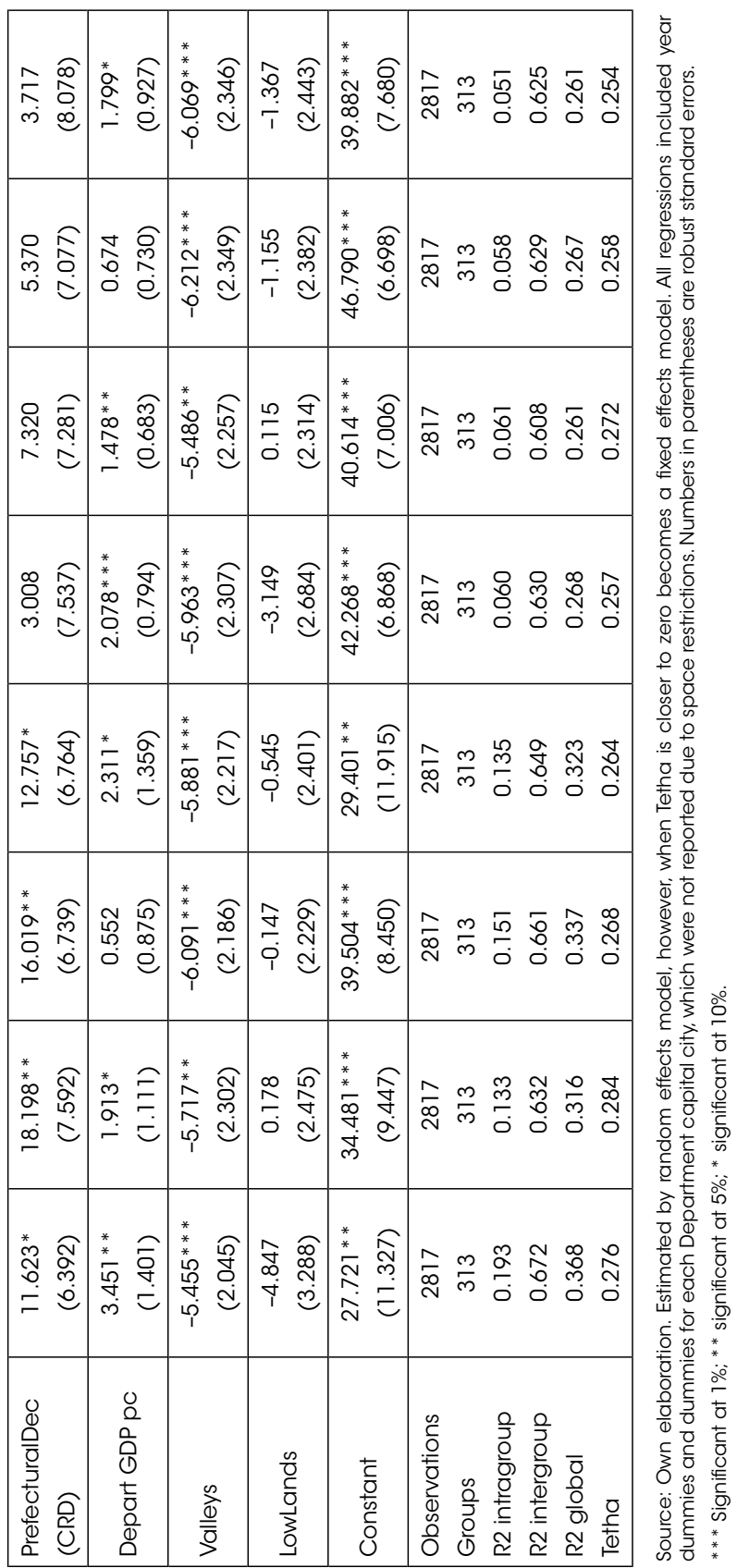




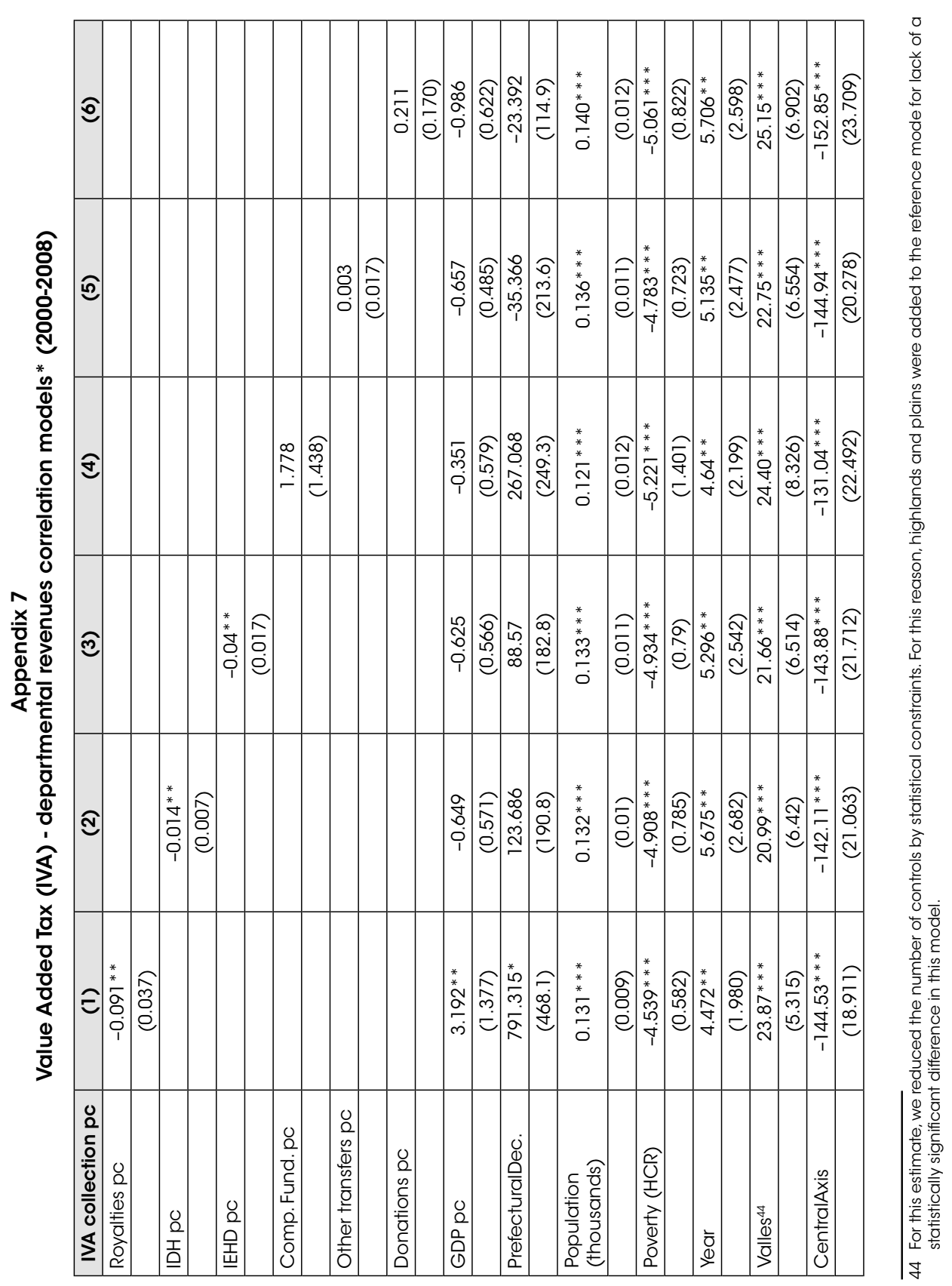




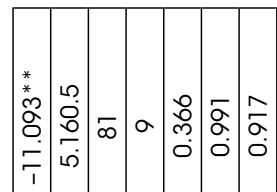

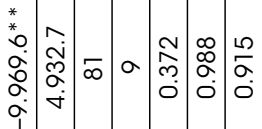

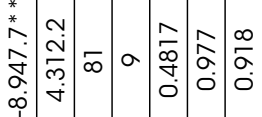

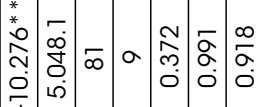

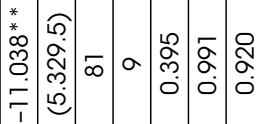

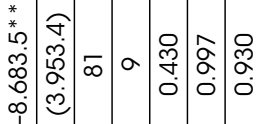

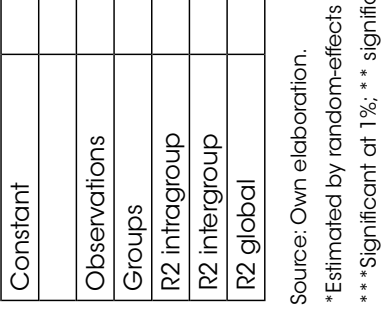
$\frac{5}{0}$
$\frac{0}{0}$
$\frac{0}{0}$
$\frac{0}{0}$
$\frac{0}{0}$
$\frac{0}{4}$
$\frac{5}{0}$
$\frac{0}{0}$

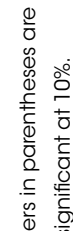
के

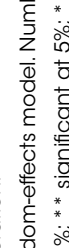

อ

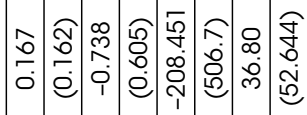

क्ष

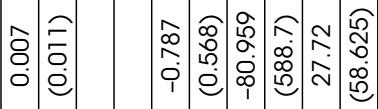
$\frac{*}{0}$

들 Ð

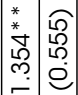

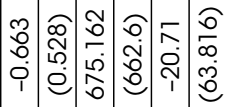
은 市

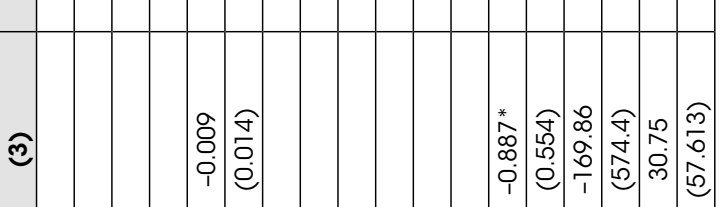
흘

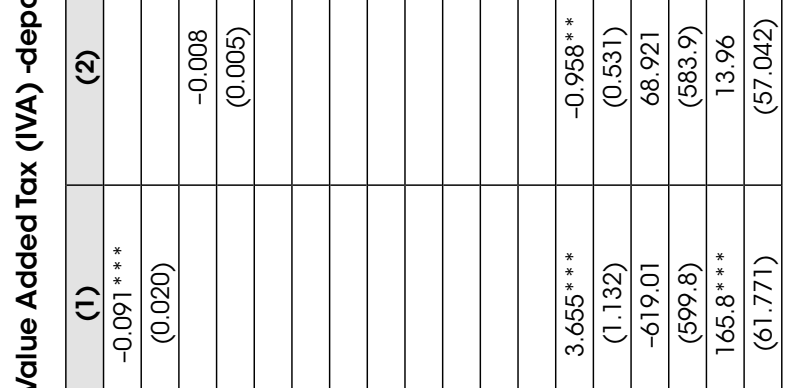
$>$

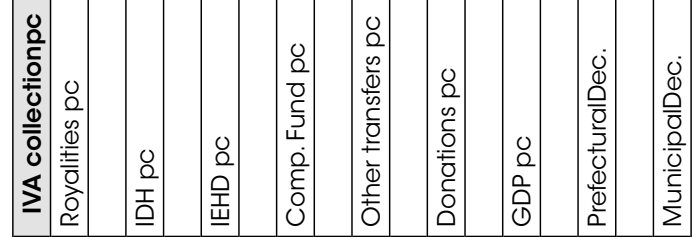




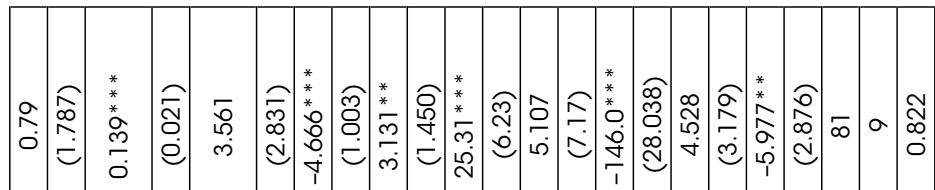

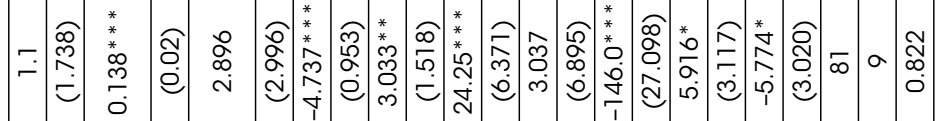

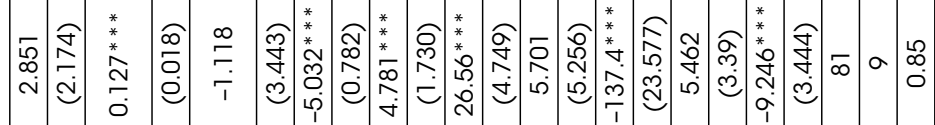

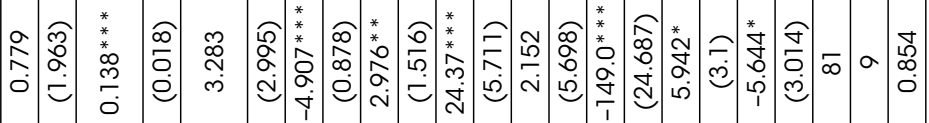

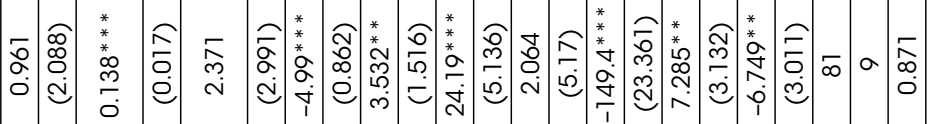

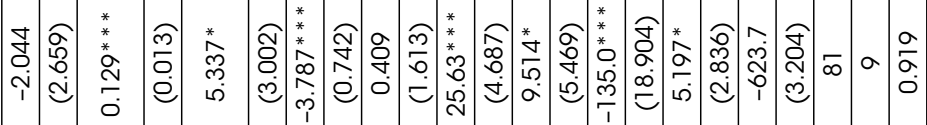

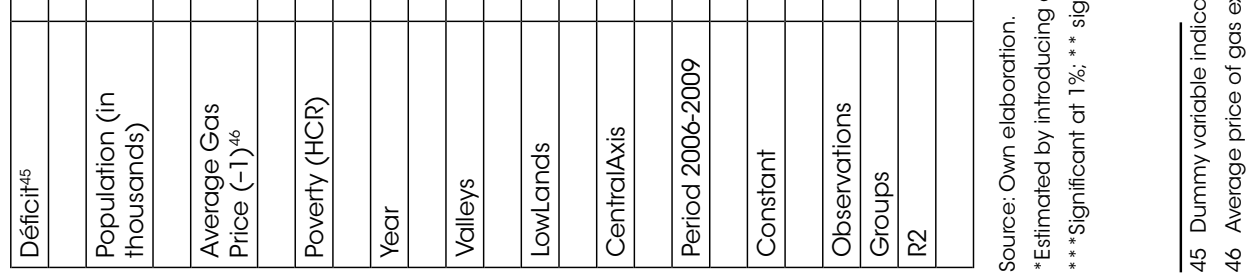


Appendix 8

Prefecture revenue-oil price correlation models ${ }^{47}$

\begin{tabular}{|c|c|c|c|c|c|c|}
\hline $\begin{array}{l}\text { Revenue } \\
\text { (thousand Bs.) }\end{array}$ & $\begin{array}{c}\text { Total } \\
\text { Revenue }\end{array}$ & $\begin{array}{c}\text { Total } \\
\text { Revenue pc }\end{array}$ & Royalties & Royalties pc & IDH + IEHD & $\begin{array}{c}\text { IDH+IEHD } \\
\text { pc }\end{array}$ \\
\hline \multirow[t]{2}{*}{ Oil price ${ }^{48}$} & $2271.2^{* * *}$ & $7.118^{* * *}$ & $838.9 * * *$ & $2.108^{* *}$ & $1451.2^{* * *}$ & $5.675^{*}$ \\
\hline & $(641.5)$ & $(1.503)$ & $(281.6)$ & $(0.980)$ & $(274.8)$ & $(3.255)$ \\
\hline \multirow[t]{2}{*}{ Gas exported } & 92.6 & 0.293 & -7.6 & -0.027 & $282.4^{* * *}$ & 0.708 \\
\hline & $(101.4)$ & $(0.271)$ & $(47.7)$ & $(0.168)$ & (67.7) & $(0.653)$ \\
\hline \multirow[t]{2}{*}{ Déficit } & $-12730 *$ & 2.537 & -427.5 & 0.576 & -1820.2 & 34.61 \\
\hline & $(7.150)$ & $(39.99)$ & $(2.370)$ & $(9.187)$ & $(2.688)$ & $(54.37)$ \\
\hline \multirow[t]{2}{*}{$\begin{array}{l}\text { Population } \\
\text { (thousands) }\end{array}$} & 297.0 & 0.060 & 151.3 & 0.301 & 2.5 & -0.258 \\
\hline & $(85.2)$ & $(0.318)$ & $(106.5)$ & $(0.174)$ & (3.7) & $(0.296)$ \\
\hline \multirow[t]{2}{*}{ Poverty (HCR) } & $-8579 *$ & $-37.19 *$ & -8.799 & $-25.41^{*}$ & -89.6 & -9.36 \\
\hline & $(4790)$ & $(22.2)$ & $(6.083)$ & (15.09) & $(295.4)$ & $(11.16)$ \\
\hline \multirow[t]{2}{*}{ Valleys } & $69.424^{* *}$ & 64.13 & 95.237 & $185.0 * *$ & -3928 & -97.97 \\
\hline & $(31.214)$ & $(149.0)$ & $(60.216)$ & $(101.9)$ & $(2.533)$ & $(138.4)$ \\
\hline \multirow[t]{2}{*}{ LowLands } & $-57.687^{* * *}$ & -94.62 & -21781 & -73.6 & $-1752^{*}$ & 38.35 \\
\hline & $(19.693)$ & $(63.83)$ & (26232) & $(47.9)$ & (977) & (34.33) \\
\hline \multirow[t]{2}{*}{ CentralAxis } & $-302.172 * *$ & -651.9 & -303.549 & $-770.0^{*}$ & 4956 & 180.9 \\
\hline & (153.079) & $(498.9)$ & $(227.448)$ & $(435.3)$ & (7847.3) & $(238.7)$ \\
\hline \multirow[t]{2}{*}{ Year 2008} & $-30.986 * *$ & $-267.6 * * *$ & $-14512 * * *$ & $-60.3 * * *$ & $-48015^{* * *}$ & $-332.3^{* * *}$ \\
\hline & $(13.171)$ & $(35.5)$ & $(5652)$ & $(20.1)$ & (6715) & $(63.3)$ \\
\hline \multirow[t]{2}{*}{ Year } & $6292 * *$ & $14.6^{*}$ & $4.039 * *$ & $11.5^{*}$ & $-12.162 * * *$ & -14.6 \\
\hline & (3039) & $(8.20)$ & $(1.876)$ & $(6.23)$ & $(2.822)$ & $(33.6)$ \\
\hline Observations & 117 & 117 & 117 & 117 & 81 & 81 \\
\hline Groups & 9 & 9 & 9 & 9 & 9 & 9 \\
\hline R2 & 0.645 & 0.1676 & 0.1876 & 0.199 & 0.925 & 0.176 \\
\hline
\end{tabular}

Source: Own elaboration.

Estimated by introducing an AR1 process. Numbers in parentheses are standard errors corrected for panel. Constants were omitted.

$* * *$ Significant at $1 \% ; *$ significant at $5 \%$; ${ }^{*}$ significant at $10 \%$.

$\overline{47}$ The first four columns covers years 1996-2008. For the last two columns the series is reduced to years $2000-2008$.

48 Both oil prices and the volume of gas exported are lagged variables. 